

\section{Green Power Marketing in the United States: A Status Report (2008 Data)}

Lori Bird, Claire Kreycik, and Barry Friedman

Prepared under Task No. SAO9.3004
Technical Report NREL/TP-6A2-46581

September 2009

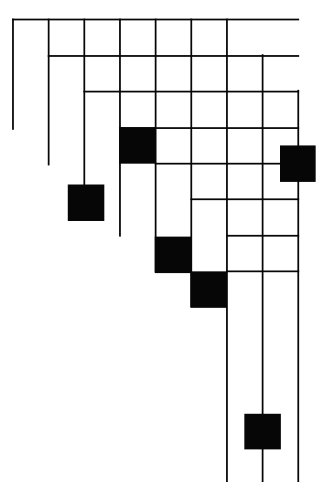




\section{NOTICE}

This report was prepared as an account of work sponsored by an agency of the United States government. Neither the United States government nor any agency thereof, nor any of their employees, makes any warranty, express or implied, or assumes any legal liability or responsibility for the accuracy, completeness, or usefulness of any information, apparatus, product, or process disclosed, or represents that its use would not infringe privately owned rights. Reference herein to any specific commercial product, process, or service by trade name, trademark, manufacturer, or otherwise does not necessarily constitute or imply its endorsement, recommendation, or favoring by the United States government or any agency thereof. The views and opinions of authors expressed herein do not necessarily state or reflect those of the United States government or any agency thereof.

Available electronically at http://www.osti.gov/bridge

Available for a processing fee to U.S. Department of Energy and its contractors, in paper, from:

U.S. Department of Energy

Office of Scientific and Technical Information

P.O. Box 62

Oak Ridge, TN 37831-0062

phone: 865.576 .8401

fax: 865.576 .5728

email: mailto:reports@adonis.osti.gov

Available for sale to the public, in paper, from:

U.S. Department of Commerce

National Technical Information Service

5285 Port Royal Road

Springfield, VA 22161

phone: 800.553 .6847

fax: 703.605.6900

email: orders@ntis.fedworld.gov

online ordering: http://www.ntis.gov/ordering.htm 


\section{Acknowledgments}

This work was funded by the U.S. Department of Energy's (DOE's) Office of Energy Efficiency and Renewable Energy (EERE). The authors wish to thank Linda Silverman and the EERE technology programs for their support of this work. The authors also wish to thank Blaine Collison of the U.S. Environmental Protection Agency; Rob Harmon of the Bonneville Environmental Foundation; Alex Pennock and Jane Valentino of the Center for Resource Solutions; Dan Lieberman and Gabe Petlin of 3Degrees Inc.; and Jim Newcomb, Gian Porro, and Jenny Sumner of NREL for their thoughtful review of the document; as well as Michelle Kubik of NREL for her editorial support. Finally, the authors thank the many green power marketers and utility contacts who provided the information summarized in this report. Additional information on green power market trends and activities can be found on the U.S. DOE's Green Power Network Web site at http://greenpower.energy.gov. 


\section{List of Acronyms}

$\begin{array}{ll}\text { aMW } & \text { average megawatt } \\ \text { DOE } & \text { Department of Energy } \\ \text { EEPS } & \text { energy efficiency portfolio standards } \\ \text { EIA } & \text { Energy Information Administration } \\ \text { EPA } & \text { Environmental Protection Agency } \\ \text { ESC } & \text { energy savings certificate } \\ \text { FCA } & \text { fuel-cost adjustment } \\ \text { kWh } & \text { kilowatt-hour } \\ \text { M\&V } & \text { measurement and verification } \\ \text { MW } & \text { megawatt } \\ \text { MWh } & \text { megawatt-hour } \\ \text { NREL } & \text { National Renewable Energy Laboratory } \\ \text { NYSERDA } & \text { New York State Energy Research and Development Authority } \\ \text { OG\&E } & \text { Oklahoma Gas \& Electric } \\ \text { PG\&E } & \text { Pacific Gas \& Electric } \\ \text { REC } & \text { renewable energy certificate } \\ \text { RGGI } & \text { Regional Greenhouse Gas Initiative } \\ \text { RPS } & \text { renewable portfolio standard } \\ \text { TRC } & \text { tradable renewable certificates }\end{array}$




\section{Table of Contents}

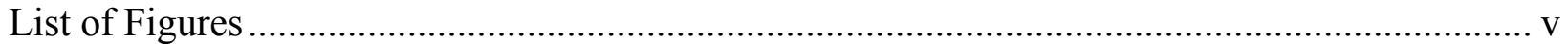

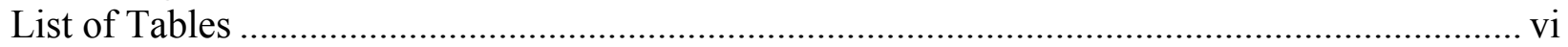

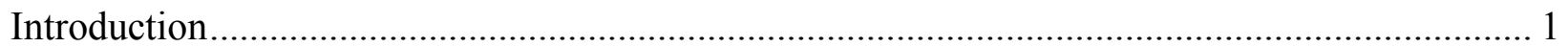

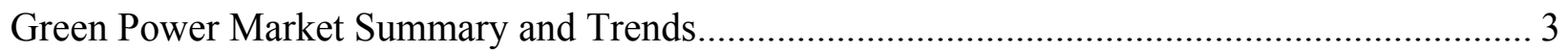

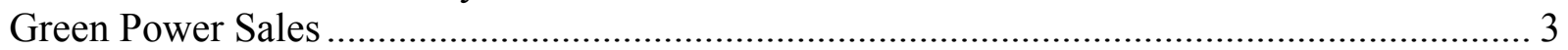

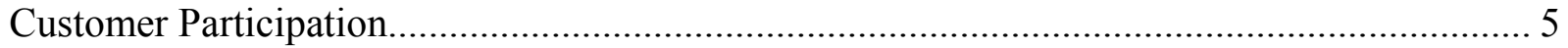

Comparison of Voluntary and Compliance Markets ................................................................. 6

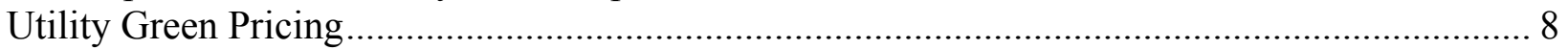

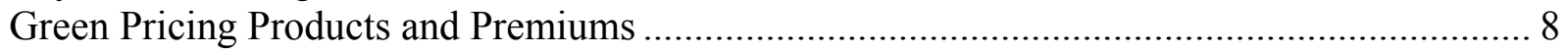

Green Pricing Customer Participation ........................................................................ 10

Green Pricing Renewable Energy Sales ......................................................................... 11

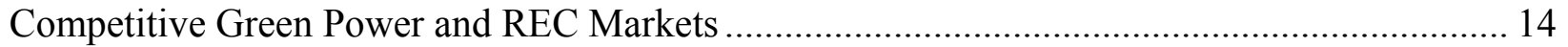

REC and Competitive-Market Products and Pricing ...................................................... 15

REC and Competitive-Market Customer Participation ........................................................ 16

REC and Competitive-Market Green Power Sales ............................................................... 18

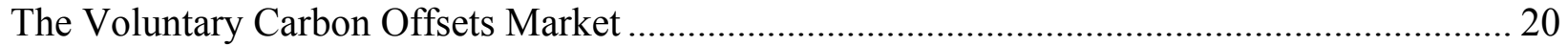

Voluntary Green Power Market Trends and Issues ..................................................................... 22

Program Marketing Expenditures: Finding the Right Balance.............................................. 22

Renewable Energy Certificate Prices................................................................................... 27

Regional REC Supply and Demand Balances .................................................................. 30

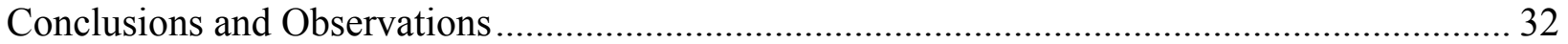

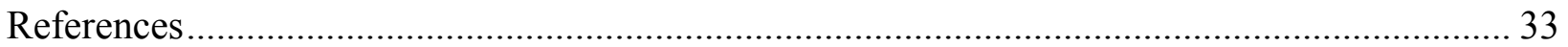

Appendix A. Estimates of Renewable Energy Capacity Serving Green Power Markets,

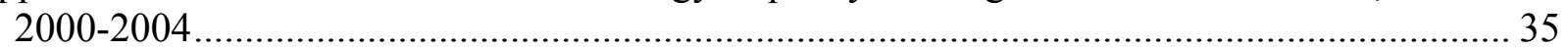

Appendix B. Top 25 Purchasers in the U.S. EPA Green Power Partnership, July 2008 ............... 36

Appendix C. Estimated U.S. Green Pricing Customers by State and Customer Class,

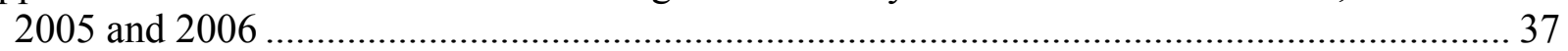

Appendix D. Utilities Offering Green Pricing Programs in Regulated Markets, 2007 ................. 39

Appendix E. Links to Utility Green Pricing Programs and REC and Competitive-Market

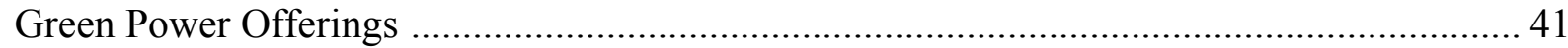

Appendix F. Top Ten Utility Green Pricing Programs ........................................................... 42

\section{List of Figures}

Figure 1. Estimated Green Power Sales By Renewable Energy Source, 2008............................. 3

Figure 2. Comparison of Voluntary and Compliance Markets for Renewable Energy, 2004-2008 . 7

Figure 3. Trends in Utility Green Pricing Premiums, 2000-2008.............................................. 9

Figure 4. Annual Sales of Renewable Energy Through Utility Green Pricing Programs

(Regulated Electricity Markets Only), Millions of Kwh ..................................................... 12

Figure 5. Growth in Retail Sales and Customer Participation for Utility/Marketer Partnerships

in Competitive Markets, 2005-2008 ………………................................................... 17

Figure 6. Average Program Marketing and Administration Expenditures By Utility Size, 2008... 22

Figure 7. Compliance Market (Primary Tier) REC Prices, 2006 to Mid-2009 ………….............. 27

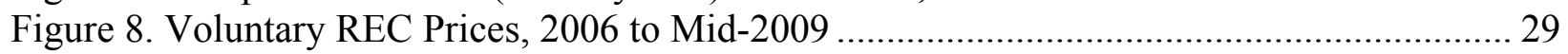

Figure 9. Snapshot of Regional Demand and Supply Under The Two Cases in 2015 (GWh)..... 31 


\section{List of Tables}

Table 1. Estimated Annual Green Power Sales by Market Sector, 2005-2008 .......................... 4

Table 2. Estimated Annual Green Power Sales by Customer Segment, 2005-2008 .................... 4

Table 3. Estimated Annual Green Power Sales by Customer Segment and Market Sector, 2008 . 5

Table 4. Estimated Cumulative Renewable Energy Capacity Supplying Green Power Markets, 2005-2008

Table 5. Estimated Cumulative Green Power Customers by Market Segment, 2002-2008 .......... 6

Table 6. Residential Price Premiums of Utility Green Power Products ( $\varnothing / \mathrm{kWh}), 2001-2008$....... 9

Table 7. Estimated Cumulative Number of Customers Participating in Utility Green Pricing

Programs (Regulated Electricity Markets Only), 2001-2008 ….................................... 10

Table 8. Customer Participation Rates in Utility Green Pricing Programs, 2002-2008............. 11

Table 9. Annual Sales of Renewable Energy through Utility Green Pricing Programs

(Regulated Electricity Markets Only), Millions of kWh, 2002-2008 ................................ 12

Table 10. Average Purchases of Renewable Energy per Customer (kWh per Year), 2002-2008 12

Table 11. Renewable Energy Generation and Capacity Supplying Green Pricing

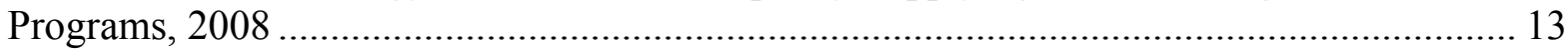

Table 12. Renewable Energy Sales as a Percent of Utility Electricity Sales, 2007-2008 .......... 13

Table 13. Total Retail Sales of Green-e Energy Certified Renewable Energy, 2007 and 2008,

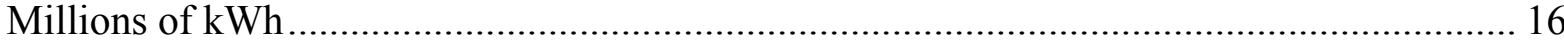

Table 14. Estimated Cumulative Number of Customers Buying RECs or Green Power from Competitive Marketers, 2003-2008 ...................................................................... 17

Table 15. Retail Sales of Renewable Energy in Competitive Markets and RECs,

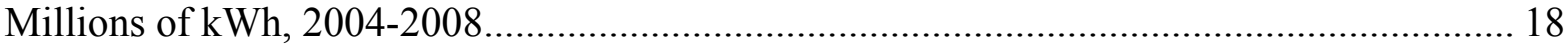

Table 16. Renewable Energy Sources Supplying Competitive and REC Markets, 2008............ 19

Table 17. GHG Offsets Sources from U.S.-Based Renewable Energy Sources, 2008................ 21

Table 18. Compliance Market SREC Prices, 2009................................................................. 28

Table 19. Range of Voluntary REC Prices in 2008 for Different Vintages (\$/MWh) ................ 29

Table A-1. Estimate Cumulative New Renewable Energy Capacity Supplying Green Power

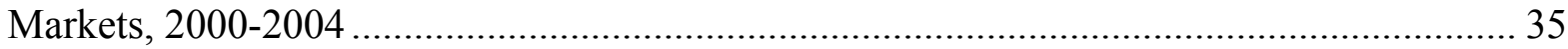

Table B-1. Top 25 Purchasers in the U.S. EPA Green Power Partnership................................. 36

Table C-1. Estimated U.S. Green Pricing Customers by State and Customer Class, 2006 and

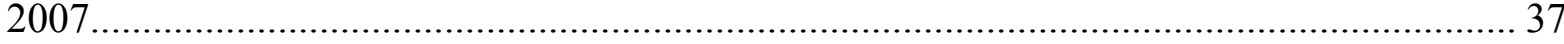

Table C-2. Estimated U.S. Green Pricing Customers by Customer Class, 2002-2007 ............... 38

Table D-1. Utilities Offering Green Pricing Programs in Regulated Markets, 2008 ................. 39

Table D-2. Utility/Marketer Green Power Programs in Restructured Electricity Markets, 2008 ... 40

Table F-1. Green Pricing Program Renewable Energy Sales (as of December 2008) ............... 42

Table F-2. Total Number of Customer Participants (as of December 2008) ............................ 43

Table F-3. Customer Participation Rate (as of December 2008) ............................................ 44

Table F-4. Green Power Sales as Percentage of Total Retail Electricity Sales (as of December 2008)............................................................................................. 45

Table F-5. Price Premium Charged for New, Customer-Driven Renewable Power (as of December 2008). 


\section{Introduction}

Voluntary consumer decisions to buy electricity supplied from renewable energy sources represent a powerful market support mechanism for renewable energy development. In the early 1990s, a small number of U.S. utilities began offering "green power" options to their customers. ${ }^{1}$ Since then, these products have become more prevalent, both from traditional utilities and from renewable energy marketers operating in states that have introduced competition into their retail electricity markets or offering renewable energy certificates (RECs) online. Today, more than half of all U.S. electricity customers have an option to purchase some type of green power product directly from a retail electricity provider, while all consumers have the option to purchase RECs.

More than 850 utilities, or about $25 \%$ of utilities nationally, offer green power programs to customers. These programs allow customers to purchase some portion of their power supply as renewable energy - almost always at a higher price - or to contribute funds for the utility to invest in renewable energy development. The term "green pricing" is typically used to refer to these utility programs offered in regulated or noncompetitive electricity markets.

In states with competitive (or restructured) retail electricity markets, electricity customers can often buy electricity generated from renewable sources by switching to an alternative electricity supplier that offers green power. In some of these states, default utility electricity suppliers offer green power options to their customers in conjunction with competitive green power marketers. ${ }^{2}$ Nearly a dozen states that have opened their markets to retail competition have experienced some green power marketing activity.

Finally, regardless of whether they have access to a green power product from their retail power provider, any consumer can purchase green power through renewable energy certificates (RECs), which represent the "environmental attributes" of electricity generated from renewable energybased projects. Consumers can also support renewable energy development through REC purchases without having to switch to an alternative electricity supplier. Today, several dozen companies actively market RECs to residential or business customers throughout the United States. Many REC marketers also sell greenhouse gas emissions offsets sourced from renewable energy projects.

This report documents green power marketing activities and trends in the United States. First, we present aggregate green power sales data for all voluntary purchase markets across the United States. The next three sections provide summary data on 1) utility green pricing programs offered in regulated electricity markets; 2) green power marketing activity in competitive electricity markets, as well as green power sold to voluntary purchasers in the form of RECs; and 3) renewable energy sold as greenhouse gas offsets in the United States. These sections are

\footnotetext{
${ }^{1}$ The term "green power" generally refers to electricity supplied in whole or in part from renewable energy sources, such as wind and solar power, geothermal, hydropower (typically low-impact or small hydro), and various forms of biomass.

${ }^{2}$ Under these programs, consumers can buy renewable energy from independent renewable energy marketing companies without switching their electricity service from the default or standard-offer service provider.
} 
followed by a discussion of key market trends and issues. The final section offers conclusions and observations. The data presented in this report are based on figures provided to NREL by utilities and independent renewable energy marketers. $^{3}$

${ }^{3}$ Green power market data for previous years are available in Bird et al. (2008), Bird et al. (2007), Bird and Swezey (2006), Bird and Swezey (2005a), Bird and Swezey (2004), Bird and Swezey (2003), Swezey and Bird (2000), and Swezey and Bird (1999). 


\section{Green Power Market Summary and Trends}

\section{Green Power Sales}

Overall, retail sales of renewable energy in voluntary purchase markets exceeded 24 billion kilowatt-hours (kWh) in 2008 , or about $0.6 \%$ of total U.S. electricity sales. ${ }^{4}$ This includes sales of renewable energy derived from both "new" and "existing" renewable energy sources, consistent with the generally accepted market definition, ${ }^{5}$ with most sales supplied from new sources. In 2008 , renewable energy sources supplied about $85 \%$ of renewable energy sold into voluntary purchase markets. ${ }^{6}$ In addition, greenhouse gas offsets sourced from new renewable energy resources-totaling nearly 250,000 tons of $\mathrm{CO}_{2}$ equivalent-were sold to U.S. voluntary purchasers in 2008 .

Wind energy represented $71 \%$ of total green power sales; followed by biomass energy sources, including landfill gas (17\%); hydropower (primarily low impact or small hydro) (9\%); geothermal (2\%); solar $(<1 \%)$; and unknown sources (1\%) (Figure 1). Based on the sales data presented in this report, we estimate the market value of green power sales in 2008 to be between \$110 million and \$190 million.

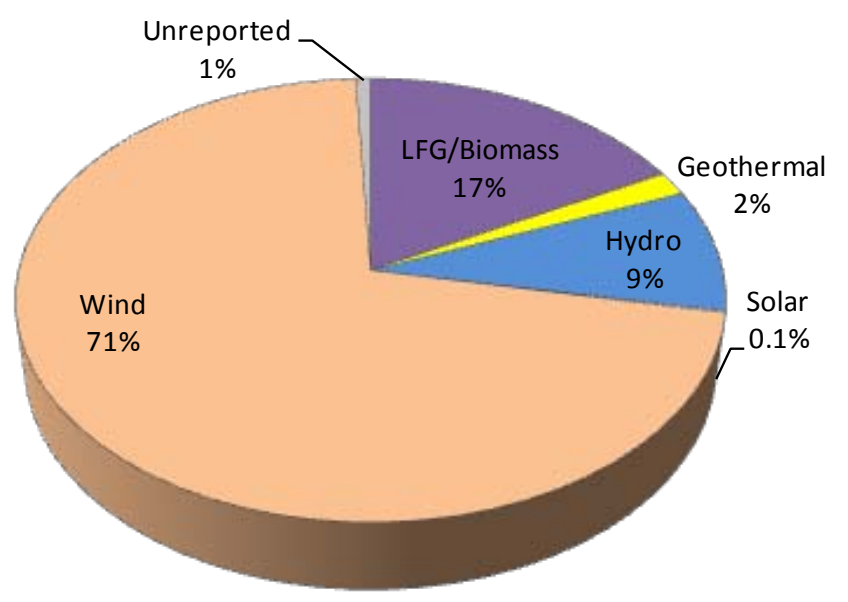

Figure 1. Estimated green power sales by renewable energy source, 2008

\footnotetext{
${ }^{4}$ U.S. electricity sales totaled 3,765 billion kWh in 2007 (2008 data are not yet available), according to the U.S. Energy Information Administration (EIA). See http://www.eia.doe.gov/cneaf/electricity/epa/epat7p2.html. The remaining renewable energy generation is rate-based by utilities or used to meet renewable portfolio standards. ${ }^{5}$ With green power, a distinction is often made based on the vintage of the renewable energy generator. The green power industry generally follows the Green-e Energy National Standard, which defines a "new" renewable generation facility as one placed in operation or repowered on or after January 1, 1997. Therefore, an "existing" generation facility is one placed in service before January 1, 1997. For more information on the Green-e Energy National Standard, see http://www.green-e.org/getcert_re_stan.shtml.

${ }^{6}$ Estimates presented in this report are primarily based on data provided by utilities and marketers and supplemented with other available data. Because we are unable to obtain data from all market participants, the estimates presented here likely underestimate the size of the entire market.
} 
Green power sales (in kilowatt-hours) increased by 34\% in 2008, with annual average growth of $41 \%$ since 2004 (Table 1). REC sales have been driving much of the growth, increasing $47 \%$ in 2008. Overall, REC markets represent nearly two-thirds of industry sales. ${ }^{7}$ Sales in competitive markets and green pricing program grew moderately in 2008; green pricing sales were dampened by the termination of one of the largest programs (Florida Power and Light Sunshine Energy Program). ${ }^{8}$

Sales to nonresidential customers continued to outpace those to residential consumers, with more than three-quarters of all sales by volume to the nonresidential sector in 2008 (Table 2). Nearly all REC sales were to business and institutional customers, while residential customers played a larger role in green pricing programs and competitive markets, where they accounted for more than $50 \%$ of renewable energy sales (Table 3 ).

Table 1. Estimated Annual Green Power Sales by Market Sector, 2005-2008* (Millions of kWh)

\begin{tabular}{|c|c|c|c|c|c|c|c|c|}
\hline Market Sector & 2005 & 2006 & 2007 & 2008 & $\begin{array}{l}\% \text { Change } \\
2004 / 2005\end{array}$ & $\begin{array}{l}\% \text { Change } \\
2005 / 2006\end{array}$ & $\begin{array}{l}\% \text { Change } \\
2006 / 2007\end{array}$ & $\begin{array}{l}\% \text { Change } \\
2007 / 2008\end{array}$ \\
\hline Utility Green Pricing & 2,500 & 3,400 & 4,300 & 4,800 & $33 \%$ & $39 \%$ & $25 \%$ & $12 \%$ \\
\hline Competitive Markets & 2,200 & $1,700^{* *}$ & 3,200 & 3,900 & $-19 \%$ & $-20 \%$ ** & $88 \%$ ** & $22 \%$ \\
\hline REC Markets ${ }^{* * *}$ & 3,900 & 6,800 & 10,600 & 15,600 & $126 \%$ & $75 \%$ & $55 \%$ & $47 \%$ \\
\hline Retail Total & 8,500 & 11,900 & 18,100 & 24,300 & $37 \%$ & $41 \%$ & $53 \%$ & $34 \%$ \\
\hline
\end{tabular}

${ }^{*}$ Includes sales of new and existing renewable energy. Totals and growth rates may not calculate due to rounding. $* \star 2006$ sales figures may be underestimated because of data gaps.

${ }^{* * *}$ Includes only RECs sold to end-use customers separate from electricity.

Table 2. Estimated Annual Green Power Sales by Customer Segment, 2005-2008* (Millions of kWh)

\begin{tabular}{|c|c|c|c|c|c|c|c|}
\hline Customer Segment & 2005 & 2006 & 2007 & 2008 & $\begin{array}{l}\% \text { Change } \\
2005 / 2006\end{array}$ & $\begin{array}{l}\% \text { Change } \\
2006 / 2007\end{array}$ & $\begin{array}{c}\% \text { Change } \\
2007 / 2008\end{array}$ \\
\hline Residential & 3,000 & 3,200 & 4,500 & 5,500 & $8 \%$ & $39 \%$ & $22 \%$ \\
\hline Nonresidential & 5,500 & 8,700 & 13,600 & 18,800 & $58 \%$ & $56 \%$ & $38 \%$ \\
\hline Total & 8,500 & 11,900 & 18,100 & 24,300 & $41 \%$ & $53 \%$ & $34 \%$ \\
\hline$\%$ Nonresidential & $65 \%$ & $73 \%$ & $75 \%$ & $77 \%$ & - & - & - \\
\hline
\end{tabular}

*Totals and growth rates may not compute due to rounding.

\footnotetext{
${ }^{7}$ The REC sales figures reflect sales to end-use customers separate from electricity. RECs bundled with electricity and sold to end-use customers through utility green pricing programs or in competitive electricity markets are counted in these other categories.

${ }^{8}$ The Florida Public Service Commission (PSC) initially acted to discontinue the program as a result of concerns over the amount of program revenues spent on marketing compared to expenditures on the renewable energy resources used to supply the program, as well as its support for out-of-state resources. However, the final basis for the decision to terminate the program, after a subsequent program audit, was related to the commission's assessment that a voluntary program was not needed after the Florida Legislature mandated an RPS. By Order No. PSC-080600-PAA-EI, issued September 16, 2008, in Docket No. 070626-EI, the commission terminated the program. http://www.floridapsc.com/library/filings/08/08720-08/08-0600.ord.doc
} 
At the end of 2008, kilowatt-hour sales of renewable energy in voluntary markets represented a generating capacity equivalent of about 7,300 MW, with about 6,300 MW of that from "new" renewable energy sources (Table 4$).{ }^{9}$ Since 2000 , the amount of renewable energy capacity serving green power markets has increased more than 40-fold (see Appendix A).

Table 3. Estimated Annual Green Power Sales by Customer Segment and Market Sector, 2008 (Millions of kWh)

\begin{tabular}{|l|c|c|c|c|}
\hline Customer Segment & $\begin{array}{c}\text { Green } \\
\text { Pricing }\end{array}$ & $\begin{array}{c}\text { Competitive } \\
\text { Markets }\end{array}$ & $\begin{array}{c}\text { REC } \\
\text { Markets }\end{array}$ & Total \\
\hline Residential & 2,600 & 2,700 & 200 & 5,500 \\
\hline Nonresidential & 2,100 & 1,200 & 15,400 & 18,700 \\
\hline Total & $\mathbf{4 , 7 0 0}$ & $\mathbf{3 , 9 0 0}$ & $\mathbf{1 5 , 6 0 0}$ & $\mathbf{2 4 , 3 0 0}$ \\
\hline$\%$ Residential & $55 \%$ & $69 \%$ & $1 \%$ & $23 \%$ \\
\hline
\end{tabular}

Note: Totals may not add due to rounding.

Table 4. Estimated Cumulative Renewable Energy Capacity Supplying Green Power Markets, 2005-2008 (Megawatts)

\begin{tabular}{|c|c|c|c|c|c|c|c|c|}
\hline Market & $\begin{array}{l}2005 \text { Total } \\
\text { Renewables } \\
\text { Capacity }\end{array}$ & $\begin{array}{c}2005 *{ }^{*} \text { New }^{*} \\
\text { Renewables } \\
\text { Capacity }\end{array}$ & $\begin{array}{c}2006 \text { Total } \\
\text { Renewables } \\
\text { Capacity }\end{array}$ & $\begin{array}{l}2006 \text { “New" } \\
\text { Renewables } \\
\text { Capacity }\end{array}$ & $\begin{array}{c}2007 \text { Total } \\
\text { Renewables } \\
\text { Capacity }\end{array}$ & $\begin{array}{c}2007 \text { “New” } \\
\text { Renewables } \\
\text { Capacity }\end{array}$ & $\begin{array}{c}2008 \text { Total } \\
\text { Renewables } \\
\text { Capacity }\end{array}$ & $\begin{array}{c}2008 * \text { New" } \\
\text { Renewables } \\
\text { Capacity }\end{array}$ \\
\hline Utility Green Pricing & 800 & 700 & 1,100 & 1,000 & 1,400 & 1,300 & 1,500 & 1,400 \\
\hline \begin{tabular}{|l|} 
Competitive \\
Markets/RECs
\end{tabular} & 1,700 & 1,300 & 2,400 & 2,100 & 3,700 & 3,000 & 5,800 & 4,900 \\
\hline Total & 2500 & 2000 & 3,500 & 3,100 & 5,100 & 4,300 & 7,300 & 6,300 \\
\hline
\end{tabular}

Note: "New" renewables capacity is a subset of total renewables capacity supplying green power markets.

\section{Customer Participation}

Based on our estimates, nearly one million electricity customers nationwide purchased green power products in 2008 through regulated utility companies, from green power marketers in a competitive-market setting, or in the form of RECs (Table 5). ${ }^{10}$ Utility green pricing programs have shown continued customer growth as the number of utility programs has increased and as existing programs have grown; however, in 2008, customer numbers did not grow in aggregate. This is largely due to the cancellation of the Florida Power and Light (FPL) Sunshine Energy Program, a large program with more than 35,000 participants prior to its termination.

Competitive-market green power participation has expanded during the past few years but has been less consistent over time, as some markets have grown and then contracted (such as in

\footnotetext{
${ }^{9}$ Capacity estimates are calculated based on reported green power kilowatt-hours sales assuming capacity factors for each renewable resource type. For wind, a capacity factor of 33\% was assumed, $90 \%$ for landfill gas, $80 \%$ for biomass, $96 \%$ for geothermal, $40 \%$ for hydroelectric, and $15 \%$ for solar electric.

${ }^{10}$ It is important to note that there is greater uncertainty in our customer estimates for competitive and REC markets because of data limitations. For more detailed estimates by state for 2006 and 2007, see data from U.S. EIA 2008 in Appendix C. Generally, our estimates are consistent with the EIA estimates when adjusted for customers in Ohio, who participated in community aggregations in 2005 and earlier. We excluded these customers from our estimates because they purchase products with very low renewable energy content ( $1 \%$ to $2 \%)$.
} 
California and Pennsylvania). The most recent growth in competitive markets has been concentrated in Texas and northeastern states. In 2008, the number of customers buying RECs increased from more than 10,000 to about 30,000, but it still represents a small fraction of the total green power market on a customer basis (but not a kilowatt-hour basis). Despite the limited number of residential customers purchasing RECs, REC sales represent nearly two-thirds of all green power kilowatt-hour sales and have grown dramatically in recent years as a result of several very large purchases (see Appendix B for a list of top green power purchasers).

Table 5. Estimated Cumulative Green Power Customers by Market Segment, 2002-2008

\begin{tabular}{|l|c|c|c|c|c|c|c|}
\hline & $\mathbf{2 0 0 2}$ & $\mathbf{2 0 0 3}$ & $\mathbf{2 0 0 4}$ & $\mathbf{2 0 0 5}$ & $\mathbf{2 0 0 6}$ & $\mathbf{2 0 0 7}$ & $\mathbf{2 0 0 8}$ \\
\hline Utility Green Pricing & 230,000 & 270,000 & 330,000 & 390,000 & 490,000 & 550,000 & 550,000 \\
\hline Competitive Markets & $\sim 150,000$ & $>170,000$ & $>140,000$ & $>180,000$ & $\sim 210,000$ & 300,000 & 390,000 \\
\hline REC Markets & $<10,000$ & $<10,000$ & $<10,000$ & $<10,000$ & $\sim 10,000$ & $>10,000$ & 30,000 \\
\hline Retail Total & $\sim 390,000$ & $\sim \mathbf{4 5 0 , 0 0 0}$ & $\sim \mathbf{4 8 0 , 0 0 0}$ & $\sim \mathbf{5 8 0 , 0 0 0}$ & $\sim \mathbf{7 1 0 , 0 0 0}$ & $\sim \mathbf{8 6 0 , 0 0 0}$ & $\sim 970, \mathbf{0 0 0}$ \\
\hline$\%$ Change & $\sim \mathbf{3 9 \%}$ & $\sim \mathbf{1 5 \%}$ & $\sim \mathbf{7 \%}$ & $\mathbf{2 1 \%}$ & $\sim \mathbf{2 2} \%$ & $\sim \mathbf{2 1 \%}$ & $\mathbf{1 3 \%}$ \\
\hline
\end{tabular}

Note: In some cases, estimates have been revised from those reported in previous NREL reports as updated data have become available. Totals may not add due to rounding.

*Includes only end-use customers purchasing RECs separate from electricity.

Average participation rates among utility green pricing programs increased slightly from $2.0 \%$ to $2.2 \%$ in 2008 , with a median value of $1.2 \%$; top performing programs have achieved rates ranging from $5 \%$ to $21 \%$. Competitive markets have experienced green power customer penetration rates ranging from $1 \%$ to $2 \%$ in the states with the most active markets; however, participation in competitive markets has been subject to market conditions and rules, and has been more volatile than in traditionally regulated markets.

\section{Comparison of Voluntary and Compliance Markets}

In 29 states and the District of Columbia, renewable portfolio standard (RPS) policies require that utilities or load-serving entities include a certain percentage of renewable energy within their power generation mix; the percentages required and eligibility requirements vary among the states. Eligible renewable energy may either be purchased by load-serving entities to meet their RPS requirements, or may be bought by consumers or businesses wanting to buy renewable energy on a voluntary basis. However, green power certification programs and state RPS policy rules generally ensure that there is no double counting between the two markets (i.e., that the same kilowatt-hour is not used for more than one purpose). "Ensuring the absence of doublecounting is important to the integrity of the market in that consumers who pay a premium for green power want to support renewable energy that would not have been otherwise supported through regulatory requirements.

In 2008, state RPS policies collectively called for utilities to procure about 23 billion $\mathrm{kWh}$ of "new" renewable energy generation (Barbose 2009), compared to about 24 billion kWh sold into

\footnotetext{
${ }^{11}$ For additional detail on the treatment of voluntary green power purchases in state RPS policies, see Holt and Wiser 2007.
} 
the voluntary green power market. ${ }^{12}$ Figure 2 shows that between 2004 and 2008, voluntary market demand for renewables slightly exceeded compliance market demand for new renewables. However, renewable energy demand to meet RPS policies is expected to grow rapidly in coming years. By 2010, RPS policies collectively call for utilities to obtain more than 60 billion $\mathrm{kWh}$ of new renewables, increasing to about 100 billion $\mathrm{kWh}$ in 2012; voluntary market growth rates would have to increase to keep pace. ${ }^{13}$

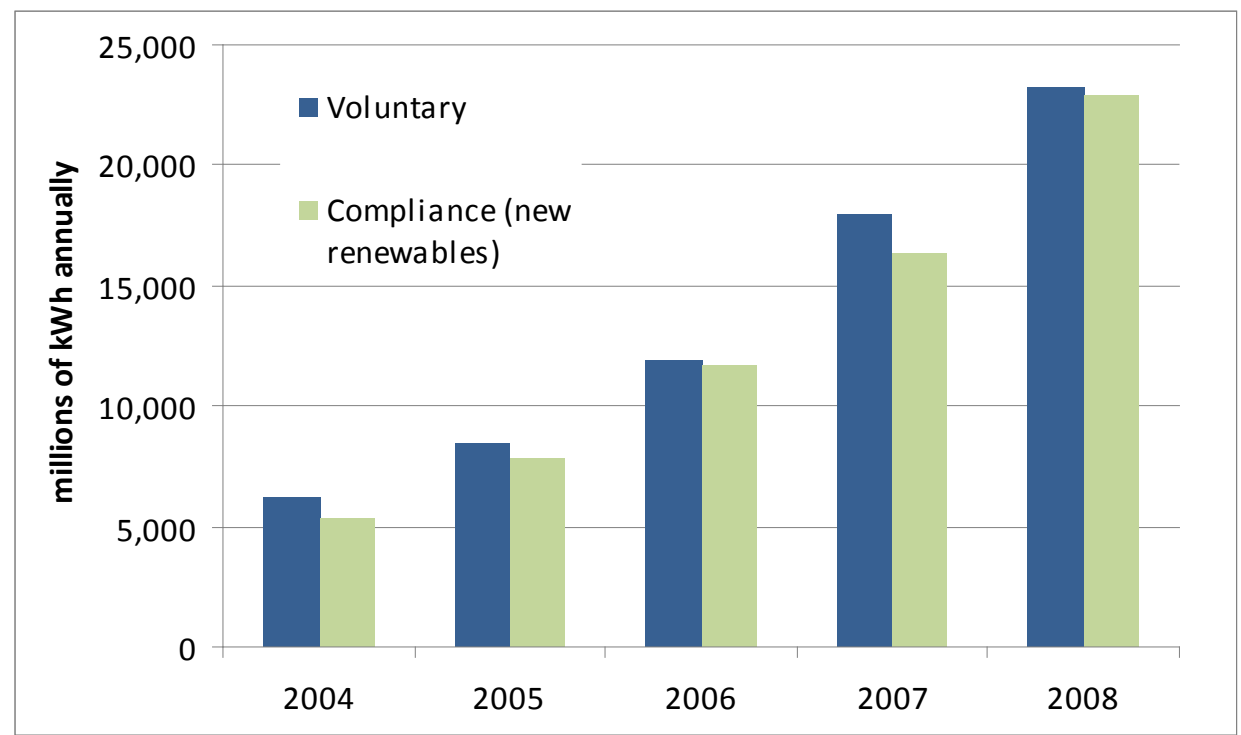

Note: Compliance market data sourced from Lawrence Berkeley National Laboratory (LBNL) (Barbose 2009)

Figure 2. Comparison of voluntary and compliance markets for renewable energy, 2004-2008

\footnotetext{
${ }^{12}$ Although RPS policies generally allow pre-existing renewable energy generation sources (i.e., those installed prior to the adoption of the RPS) to meet their targets, the estimates presented here reflect only the amount of new renewable energy generation that these policies are expected to stimulate. These figures are compared to the voluntary market estimates, because voluntary markets primarily support generation from new renewable energy projects (i.e., those installed after voluntary green power markets were established). Estimates of compliance market demand assume that RPS targets are fully met.

${ }^{13}$ This figure does not include the Kansas RPS because the Kansas Corporation Commission has not yet developed the methodology for calculating utility's peak demand, so the amount of renewable generation required to meet the RPS is not yet known.
} 


\section{Utility Green Pricing}

This section provides information specific to utility green pricing programs, a subset of the market. The number of utilities offering green pricing has grown steadily in recent years - today, more than 850 investor-owned, public, and cooperative utilities in most states offer green pricing programs. Appendix D provides a list of utilities offering green pricing, and Appendix E provides Web links to all green power product offerings. ${ }^{14}$ Because a number of small municipal or cooperative utilities offer programs developed by their power suppliers, the number of distinct green pricing programs is about 160 . Some states have adopted laws requiring utilities to offer consumers green power options, which have driven the development of new programs in some states. $^{15}$

\section{Green Pricing Products and Premiums}

Typically, green pricing programs are structured so that customers can either purchase green power for a certain percentage of their electricity use (often called "percent-of-use products") or in discrete amounts or blocks at a fixed price ("block products"), such as a $100 \mathrm{kWh}$ block. Most utilities offer block products but may also allow customers to buy green power for their entire monthly electricity use. Utilities that offer percent-of-use products generally allow residential customers to elect to purchase $25 \%, 50 \%$, or $100 \%$ of their electricity use as renewable energy, while a few offer fractions as small as $10 \%$. Under these types of programs, larger purchasers, such as businesses, can often purchase green power for some fraction of their electricity use as well.

In 2008, the price of green power for residential customers in utility programs ranged from $-1.0 \notin / \mathrm{kWh}$ (a savings compared to standard service) to $8.8 \phi / \mathrm{kWh}$ above standard electricity rates, with an average premium of $1.8 \phi / \mathrm{kWh}$ and median of $1.5 \phi / \mathrm{kWh}$. These premiums have been adjusted to account for any fuel-cost exemptions granted to green power program participants. ${ }^{16}$ In 2008, the utility programs with the lowest premiums for energy derived from new renewable sources had premiums ranging from $-1.0 \notin / \mathrm{kWh}$ (a savings) to $0.9 \phi / \mathrm{kWh}$. On average, consumers spend about $\$ 5.40$ per month above standard electricity rates for green power through utility programs, which is consistent with previous years.

Since 2000, the average price premium has dropped at an average annual rate of $8 \%$ (Table 6; Figure 3). Some of this reduction can be attributed to lower market costs for renewable energy supplies, although changes in market conditions since mid-2008 have made these trends less clear. In recent years, increases in the price of natural gas narrowed the price gap between renewables and gas-fired generation alternatives, leading to lower initial premiums for many new programs; however, since the economic downturn in mid- to late-2008, natural gas prices have fallen dramatically, reversing this trend. Although wind was generally competitive with wholesale power prices in 2008, a drop in these prices may pose additional challenges for its

\footnotetext{
${ }^{14}$ For an up-to-date list of utilities with green pricing programs, see the U.S. Department of Energy's Green Power Network Web site at http://apps3.eere.energy.gov/greenpower/markets/pricing.shtml?page=1.

${ }^{15}$ These states include Colorado, Iowa, Minnesota, Montana, New Mexico, Oregon, Vermont, and Washington.

${ }^{16}$ For example, some utilities exempt green pricing customers from monthly or periodic fuel charges imposed to pay higher than expected fossil-fuel costs. For a more detailed discussion of this topic, see Bird et al. (2008).
} 
competitiveness in 2009 (Wiser and Bolinger 2009). The competitiveness of wind and other renewables with conventional generation, as well as regional demand from state renewable energy standards (and national demand if a federal standard is adopted), will affect premiums in coming years.

Table 6. Residential Price Premiums of Utility Green Power Products ( $\phi / \mathrm{kWh}$ ), 2001-2008

\begin{tabular}{|c|c|c|c|c|c|c|c|c|}
\hline & 2001 & 2002 & 2003 & 2004 & 2005 & 2006 & $2007^{*}$ & $2008^{*}$ \\
\hline $\begin{array}{l}\text { Average } \\
\text { Premium }\end{array}$ & 2.93 & 2.82 & 2.62 & 2.45 & 2.36 & 2.12 & 1.85 & 1.8 \\
\hline Median Premium & 2.5 & 2.5 & 2 & 2 & 2 & 1.78 & 1.5 & 1.5 \\
\hline $\begin{array}{l}\text { Range of } \\
\text { Premiums }\end{array}$ & 0.9-17.6 & $0.7-17.6$ & $0.6-17.6$ & $\begin{array}{c}0.33- \\
17.6 \\
\end{array}$ & $(0.7)-17.6$ & $(0.1)-17.6$ & $0.09-7.5$ & $(-1.0)-8.8$ \\
\hline $\begin{array}{l}10 \text { Programs } \\
\text { with Lowest } \\
\text { Premiums }{ }^{\star *}\end{array}$ & $1.0-1.5$ & $0.7-1.5$ & $0.6-1.3$ & $0.33-1.0$ & $(0.7)-0.9$ & $(0.1)-1.0$ & $0.09-0.8$ & $(-1.0)-0.9$ \\
\hline $\begin{array}{l}\text { Number of } \\
\text { Programs } \\
\text { Represented }\end{array}$ & 60 & 80 & 91 & 101 & 104 & 97 & 71 & 86 \\
\hline \multicolumn{9}{|c|}{$\begin{array}{l}\text { *In later years, calculations of premiums w ere based on programs that responded to the questionnaire. In previous years, a larger sample } \\
\text { of programs was used to calculate the premium, as data w ere available. }\end{array}$} \\
\hline $\begin{array}{l}{ }^{* *} \text { Represents the } 10 \\
\text { programs that have ir } \\
\text { discrepancy betw eer } \\
\text { premium }(0.9 \phi / k W h) \\
\text { renew able capacity } \mathrm{f}\end{array}$ & $\begin{array}{l}\text { ility programs } \\
\text { talled-or an } \\
\text { the low end } \\
\text { t being eligib } \\
r \text { its program }\end{array}$ & $\begin{array}{l}N \text { ith the low } \\
\text { ounced firm } \\
\text { the range } f \\
\text { for the Top }\end{array}$ & $\begin{array}{l}\text { t price prer } \\
\text { ans to insta } \\
\text { all program } \\
\text { because i }\end{array}$ & $\begin{array}{l}\mathrm{ms} \text { for nev } \\
\text { or purchas } \\
\text { and the To } \\
\text { as either }\end{array}$ & $\begin{array}{l}\text { customer-dr } \\
\text { pow er from } \\
10 \text { programs } \\
\text { elling some ex }\end{array}$ & $\begin{array}{l}\text { ven renew ab } \\
\text {-new renew } \\
\text { results from } t \\
\text { isting renew }\end{array}$ & $\begin{array}{l}\text { energy. This } \\
\text { e energy sou } \\
\text { program w it } \\
\text { es or had not }\end{array}$ & $\begin{array}{l}\text { des only } \\
\text { In } 2001 \text { the } \\
\text { low est } \\
\text { lled any new }\end{array}$ \\
\hline
\end{tabular}

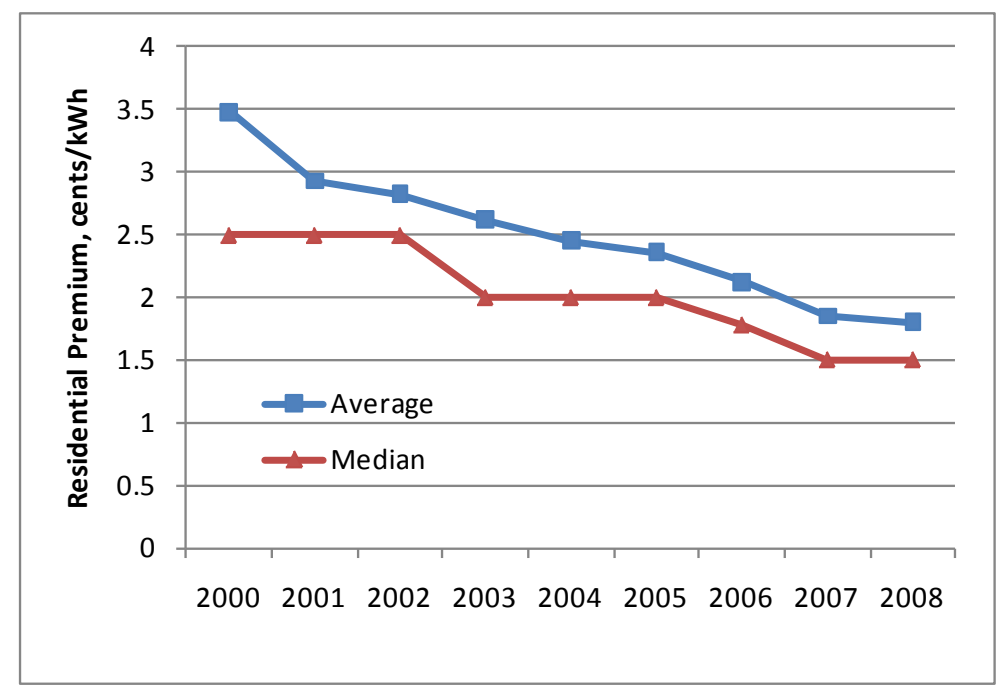

Figure 3. Trends in utility green pricing premiums, 2000-2008 


\section{Green Pricing Customer Participation}

At the end of 2008, about 550,000 customers were participating in utility green pricing programs in regulated electricity markets (Table 7). ${ }^{17}$ As in the past, a relatively small number of green power programs account for the majority of customers, with just 10 programs accounting for almost $70 \%$ of all participants (Appendix F). ${ }^{18}$ From 2001 to 2007, the number of customer participants increased more than threefold, but this trend reversed in 2008. With the cancellation of the large FPL program, nearly 40,000 customers left the market, and total participants in utility programs nationwide fell slightly. Without the loss of the FPL program, the number of participants in utility green power programs would have grown modestly, by about $6 \% .{ }^{19}$

The decline in the economy, particularly in the second half of 2008, likely contributed to smaller gains in participants relative to previous years and a number of programs reported losses in the total number of participants. Perhaps surprisingly, nonresidential participant growth was on par with 2007; while the reason for this increase is unclear, one possible explanation could be heightened interest in renewable energy issues in an election year in which renewables and climate change were a focus. It is also possible that some programs placed greater emphasis on attracting commercial customers to make up for residential customer losses, as a number of programs that reported losing residential customers, reported overall gains in sales as a result of increased nonresidential sales.

Table 7. Estimated Cumulative Number of Customers Participating in Utility Green Pricing Programs (Regulated Electricity Markets Only)

\begin{tabular}{|c|c|c|c|c|c|c|c|c|}
\hline Customer Segment & 2001 & 2002 & 2003 & 2004 & 2005 & 2006 & 2007 & 2008 \\
\hline Residential & 166,300 & 224,500 & 258,700 & 323,700 & 383,400 & 470,800 & 526,700 & 519,700 \\
\hline Nonresidential & 2,500 & 3,900 & 6,500 & 8,100 & 11,300 & 15,500 & 20,200 & 26,100 \\
\hline Total & 168,800 & 228,400 & 265,200 & 331,800 & 394,700 & 486,300 & 546,900 & 545,800 \\
\hline$\%$ Total Annual Growth & $27 \%$ & $35 \%$ & $16 \%$ & $25 \%$ & $19 \%$ & $23 \%$ & $12 \%$ & $0 \%$ \\
\hline$\%$ Residential Growth & $27 \%$ & $35 \%$ & $15 \%$ & $25 \%$ & $18 \%$ & $23 \%$ & $12 \%$ & $-1 \%$ \\
\hline$\%$ Nonresidential Growth & $47 \%$ & $56 \%$ & $67 \%$ & $25 \%$ & $40 \%$ & $37 \%$ & $30 \%$ & $29 \%$ \\
\hline
\end{tabular}

Table 7 delineates residential and nonresidential customer participation in utility green pricing programs over time. The vast majority of participants are residential customers, with

\footnotetext{
${ }^{17}$ NREL obtained consumer response data for about two-thirds of utility green pricing programs in 2008, including all of the major programs. The remaining programs, which are smaller in size, do not have a large impact on overall participant numbers. Wherever possible, other sources and previously reported data were used to estimate data gaps.

${ }^{18}$ NREL issues five different Top 10 lists based on total sales of renewable energy to program participants, total number of customer participants, customer participation rates, green power sales as a fraction of total utility sales, and the premium charged to support new renewables development. These lists can be found at http://apps3.eere.energy.gov/greenpower/markets/pricing.shtml?page=3.

${ }^{19}$ The Florida Public Service Commission (PSC) initially acted to discontinue the program as a result of concerns over the amount of program revenues spent on marketing compared to expenditures on the renewable energy resources used to supply the program, as well as its support for out-of-state resources. However, the final basis for the decision to terminate the program, after a subsequent program audit, was related to the commission's assessment that a voluntary program was not needed after the Florida Legislature mandated an RPS. By Order No. PSC-080600-PAA-EI, issued September 16, 2008, in Docket No. 070626-EI, the commission terminated the program. http:/www.floridapsc.com/library/filings/08/08720-08/08-0600.ord.doc
} 
nonresidential customers accounting for only $5 \%$ of all participants. However, nonresidential participation is growing at a faster rate than residential participation, which is having a significant positive impact on overall sales volume because of the larger size of nonresidential purchases.

At the end of 2008, the average participation rate in utility green pricing programs among eligible utility customers was $2.2 \%$, with a median of $1.2 \%$ (Table 8 ). These industry-wide rates have shown little change in recent years. The overall lack of improvement in participation rates results from a number of factors, including a customer unwillingness to pay a premium for green power, and varied levels of interest among utilities in marketing and promoting the program (Holt and Holt 2004, Swezey and Bird 2001). However, the top-performing programs continue to show improvement, with participation rates ranging from about $5 \%$ to $21 \%$ in 2008 , compared to a range of $3 \%$ to $6 \%$ in 2002 . The $20 \%$ participation threshold was exceeded for the first time in 2007.

Table 8. Customer Participation Rates in Utility Green Pricing Programs, 2002-2008

\begin{tabular}{|l|c|c|c|c|c|c|c|}
\hline Participation Rate & $\mathbf{2 0 0 2}$ & $\mathbf{2 0 0 3}$ & $\mathbf{2 0 0 4}$ & $\mathbf{2 0 0 5}$ & $\mathbf{2 0 0 6}$ & $\mathbf{2 0 0 7}$ & $\mathbf{2 0 0 8}$ \\
\hline Average & $1.2 \%$ & $1.2 \%$ & $1.3 \%$ & $1.5 \%$ & $1.8 \%$ & $2.0 \%$ & $2.2 \%$ \\
\hline Median & $0.8 \%$ & $0.9 \%$ & $1.0 \%$ & $1.0 \%$ & $1.0 \%$ & $1.3 \%$ & $1.2 \%$ \\
\hline \multirow{2}{*}{ Top 10 Programs } & $3.0 \%-$ & $3.9 \%-$ & $3.8 \%-$ & $4.6 \%-$ & $5.1 \%-$ & $5.2 \%-$ & $5.0 \%-$ \\
\hline
\end{tabular}

In 2008, utilities reported that an average of 5.5\% and a median of $2.5 \%$ of customers dropped out of green pricing programs. Retention rates are still relatively high despite the fact that electricity and energy prices remained high in most regions of the country throughout most of the year. This finding suggests that customers tend to be "sticky" and maintain participation in green power programs, despite electricity and other energy cost increases. While data on the reason for dropouts is not available, anecdotal evidence from some utilities suggests that customer moves can be a significant source of dropouts. Most utilities (about 70\%) do not impose minimum periods for which customers must subscribe to the green power program. If a minimum term is imposed, it is most commonly one year-although there are several programs that offer fixedprice green power for contracts of longer durations.

\section{Green Pricing Renewable Energy Sales}

Utility green pricing sales continue to exhibit some growth, but growth has slowed in the past two years, in particular. Collectively, utilities in regulated electricity markets sold about 4.8 billion $\mathrm{kWh}$ of green power to customers in 2008 (Table 9). Green pricing program sales to all customer classes grew by $11 \%$ in 2008 , compared to rates ranging from $26 \%$ to $56 \%$ in recent years (Table 9 and Figure 4). The loss of the FPL program had a noticeable impact on sales. Without the termination of the FPL program, utility green pricing program sales would have grown at a rate of $22 \%$ in 2008, similar to growth in 2007.

Sales growth is mostly attributed to increases in the number of nonresidential customers and larger purchases; in 2008, the average nonresidential purchase nearly doubled from the 2007 average (Table 10). Although the reason for these increased purchases is not known, it could be 
attributed to declines in green power prices for nonresidential retail customers, or enrollment of larger commercial and industrial customers. As noted earlier, some programs may have also placed greater emphasis on marketing to the commercial sector to make up for residential customer losses.

Table 9. Annual Sales of Renewable Energy through Utility Green Pricing Programs (Regulated Electricity Markets Only), Millions of kWh, 2002-2008

\begin{tabular}{|l|c|c|c|c|c|c|c|}
\hline & $\mathbf{2 0 0 2}$ & $\mathbf{2 0 0 3}$ & $\mathbf{2 0 0 4}$ & $\mathbf{2 0 0 5}$ & $\mathbf{2 0 0 6}$ & $\mathbf{2 0 0 7}$ & $\mathbf{2 0 0 8}$ \\
\hline $\begin{array}{l}\text { Sales to } \\
\text { Residential }\end{array}$ & 660 & 870 & 1,300 & 1,610 & 2,100 & 2,550 & 2,660 \\
\hline $\begin{array}{l}\text { Sales to } \\
\text { Nonresidential }\end{array}$ & 230 & 410 & 540 & 840 & 1,300 & 1,630 & 2,150 \\
\hline $\begin{array}{l}\text { Total Sales to } \\
\text { All customers }\end{array}$ & $\mathbf{9 0 0}$ & $\mathbf{1 , 2 8 0}$ & $\mathbf{1 , 8 4 0}$ & $\mathbf{2 , 4 5 0}$ & $\mathbf{3 , 4 0 0}$ & $\mathbf{4 , 2 9 0}$ & $\mathbf{4 , 8 1 0}$ \\
\hline $\begin{array}{l}\text { \% Annual } \\
\text { Growth in Total }\end{array}$ & $\mathbf{5 6 \%}$ & $\mathbf{4 3 \%}$ & $\mathbf{4 3 \%}$ & $\mathbf{3 3 \%}$ & $\mathbf{3 9 \%}$ & $\mathbf{2 6 \%}$ & $\mathbf{1 2 \%}$ \\
\hline $\begin{array}{l}\text { \% Nonresidential } \\
\text { of Total Sales }\end{array}$ & $26 \%$ & $32 \%$ & $30 \%$ & $34 \%$ & $38 \%$ & $38 \%$ & $32 \%$ \\
\hline
\end{tabular}

Note: Totals may not add due to rounding.

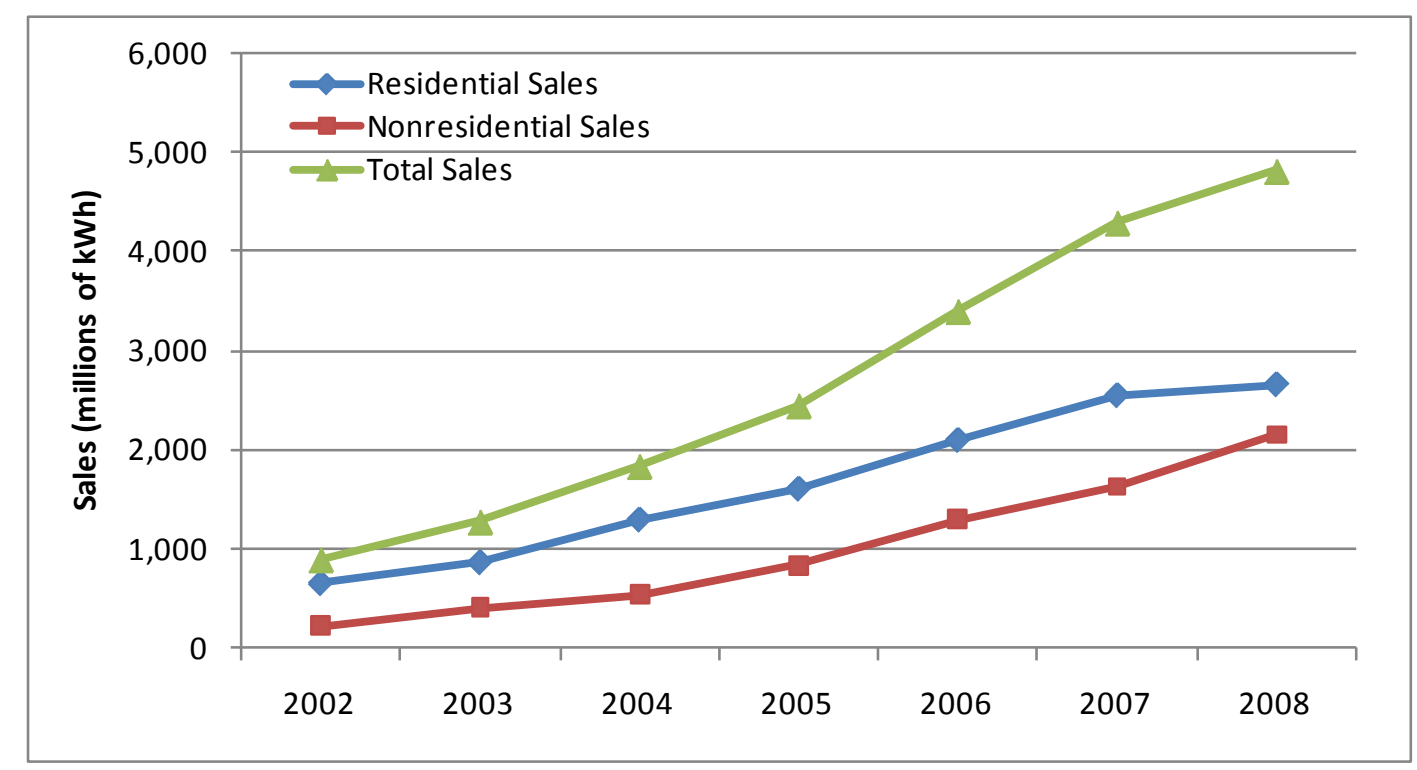

Figure 4. Annual sales of renewable energy through utility green pricing programs, 2002-2008 (regulated electricity markets only)

Table 10. Average Purchases of Renewable Energy per Customer (kWh per Year), 2002-2008

\begin{tabular}{|l|c|c|c|c|c|c|c|}
\hline & $\mathbf{2 0 0 2}$ & $\mathbf{2 0 0 3}$ & $\mathbf{2 0 0 4}$ & $\mathbf{2 0 0 5}$ & $\mathbf{2 0 0 6}$ & $\mathbf{2 0 0 7}$ & $\mathbf{2 0 0 8}$ \\
\hline Residential Customers & 2,900 & 3,400 & 4,000 & 4,200 & 4,400 & 4,900 & 5,500 \\
\hline Nonresidential Customers & 60,000 & 63,100 & 67,200 & 74,500 & 85,700 & 77,400 & 141,300 \\
\hline All Customers & 3,900 & 4,800 & 5,500 & 6,200 & 6,700 & 7,400 & 20,800 \\
\hline
\end{tabular}


About $95 \%$ of the renewable energy sold to consumers through green pricing programs was supplied from projects meeting the generally accepted industry definition of "new." Renewable energy sold through green pricing programs in 2008 represents an equivalent renewable energy capacity of more than 1,500 MW, with more than 1,400 MW of this represented by "new" renewable energy resources (Table 11). ${ }^{20}$ Wind, solar, landfill gas, and other biomass are the renewable resources most commonly included in utility programs; although solar, in particular, may be used to supply a small fraction of kilowatt-hour sales. Wind energy represents the largest portion of the total capacity. In 2007, sales of renewable energy through green pricing programs represented more than 1,400 MW of renewable energy capacity, with about 1,300 MW of that from new renewable energy sources. Table 4 and Appendix A present estimates of new capacity serving green pricing programs in earlier years.

Table 11. Renewable Energy Generation and Capacity Supplying Green Pricing Programs, 2008

\begin{tabular}{|l|c|c|c|c|c|c|c|c|}
\hline & $\begin{array}{c}\text { Landfill } \\
\text { Gas }\end{array}$ & $\begin{array}{c}\text { Other } \\
\text { Biomass }\end{array}$ & $\begin{array}{c}\text { Geo- } \\
\text { thermal }\end{array}$ & Hydro & Solar & Wind & Unknown & Total \\
\hline Sales MWh & 343,000 & 202,000 & 75,000 & 52,000 & 9,000 & $3,993,000$ & 143,000 & $4,817,000$ \\
\hline$\%$ of Total Sales & $7 \%$ & $4 \%$ & $2 \%$ & $1 \%$ & $0.2 \%$ & $83 \%$ & $3 \%$ & $100 \%$ \\
\hline Total MW & 44 & 29 & 9 & 15 & 7 & 1,381 & 33 & 1,517 \\
\hline MW New RE & 41 & 28 & 9 & 14 & 7 & 1,341 & - & 1,440 \\
\hline
\end{tabular}

In 2008, green power sales represented a small but increasing proportion of a utility company's overall energy sales. Table 12 shows that, on average, renewable energy sold through green pricing programs in 2008 represented approximately 1\% of total utility electricity sales (on a $\mathrm{kWh}$ basis), while a few utilities reported fractions as high as about $5 \%$ to $6 \%$ of total retail electricity sales. On a residential basis, green power sales represented a higher fraction of total utility electricity sales, with one utility reporting a fraction as high as $23 \%$.

Table 12. Renewable Energy Sales as a Percent of Utility Electricity Sales, 2007-2008

\begin{tabular}{|l|c|c|c|c|c|c|}
\hline & \multicolumn{3}{|c|}{2007} & \multicolumn{3}{c|}{ 2008 } \\
\hline Customer Class & Avg. & Med. & Range & Avg. & Med. & Range \\
\hline Residential & $1.4 \%$ & $0.6 \%$ & $0 \%-17.4 \%$ & $1.5 \%$ & $0.5 \%$ & $0 \%-23.4 \%$ \\
\hline Nonresidential & $0.5 \%$ & $0.2 \%$ & $0 \%-6.3 \%$ & $0.8 \%$ & $0.2 \%$ & $0 \%-12.0 \%$ \\
\hline All customers & $0.8 \%$ & $0.3 \%$ & $0 \%-5.7 \%$ & $1.0 \%$ & $0.4 \%$ & $0 \%-6.4 \%$ \\
\hline
\end{tabular}

\footnotetext{
${ }^{20}$ Capacity estimates are calculated based on reported green power kilowatt-hours sales assuming capacity factors for each renewable resource type. For wind, a capacity factor of 33\% was assumed, $90 \%$ for landfill gas, $80 \%$ for biomass, $96 \%$ for geothermal, $40 \%$ for hydroelectric, and $15 \%$ for solar electric. Estimates of megawatts in previous years' projections were higher on a relative basis due to the capacity factor assumed for wind. In prior years a $30 \%$ capacity factor was assumed, but in 2008 estimates of MW were based on a 33\% capacity factor to reflect improvements in capacity factors as a result of the movement toward larger turbines as well as greater reliance on projects in areas with strong wind resources. For every million MWh, this accounts for a discrepancy of $35 \mathrm{MW}$ of capacity in the estimates.
} 


\section{Competitive Green Power and REC Markets}

This section provides greater detail on green power sold in competitive (or restructured) electricity markets as well as in the form of RECs - subsets of the entire green power market. About one-quarter of U.S. states have restructured their electricity markets for retail service competition. Currently, electricity consumers in the following states can purchase competitively marketed green power: Connecticut, Illinois, Maine, Maryland, Massachusetts, New Jersey, New York, Pennsylvania, Rhode Island, Texas, and the District of Columbia. ${ }^{21,22}$ Competitively marketed green power offerings are also available to nonresidential consumers in a few other states.

Initially, buying green power in competitive retail markets entailed switching electricity service from the incumbent utility to a green power supplier. However, with few exceptions, green power marketers have found it difficult to compete or to persuade customers to switch suppliers. As a remedy, a number of states now require default suppliers (which are often the incumbent distribution utilities) to offer green power options to their customers. These load-serving entities typically provide customers with underlying electricity generation, combined with a choice of several green products offered by competing green power marketers. In addition, several utility suppliers have voluntarily teamed with a single green power marketer to offer a green power option to their customers. Such programs are now offered in Connecticut, Massachusetts, New Jersey, New York, Pennsylvania, and Rhode Island.

RECs provide another alternative to switching electricity suppliers. Also known as green certificates, green tags, or tradable renewable certificates (TRCs), RECs represent the "green" attributes of renewable energy generation and can be sold separately from commodity electricity. REC-based products may be supplied from a variety of renewable energy sources throughout the country and sold to customers nationally, or they may be supplied from renewable energy sources in a particular region or locality and marketed as such to local customers. More than 25 companies offer certificate-based green power products to retail customers via the Internet, and a number of other companies market RECs solely to commercial and industrial customers. ${ }^{23}$

RECs are also sold in the wholesale market and are frequently used by utilities and marketers who bundle RECs with commodity electricity to sell green power to retail customers. In fact, RECs are used to supply most of the programs where default suppliers have teamed with green

\footnotetext{
${ }^{21}$ For an up-to-date list of products offered by competitive green power marketers, see the U.S. Department of Energy's Green Power Network Web site at: http://apps3.eere.energy.gov/greenpower/markets/marketing.shtml?page=1.

${ }^{22}$ We do not include Oregon and Virginia in this list. In Oregon, only large commercial and industrial customers are able to switch to competitive green power providers; residential and small commercial customers have access to green power options offered by the incumbent utilities, which we categorize as green pricing. In Virginia, at least one retail electricity provider provided green power options in 2007 and earlier, but does not do so currently.

${ }^{23}$ For an up-to-date list of companies offering REC-based green power products, see the U.S. Department of Energy's Green Power Network Web site at: http://apps3.eere.energy.gov/greenpower/markets/certificates.shtml?page=1. For a list of REC suppliers serving commercial or wholesale customers, see: http://apps3.eere.energy.gov/greenpower/markets/certificates.shtml?page $=4$.
} 
power marketers. Therefore, it can be difficult to distinguish REC products from other green power offerings. This is particularly true when REC products are supplied from renewable sources located in the same region where they are marketed.

\section{REC and Competitive-Market Products and Pricing}

Green power products offered in competitive markets tend to differ from those offered by utilities in regulated markets, as they are more likely to be sourced from RECs because suppliers may be less able to enter into long-term contracts with generators. In addition, price premiums may fluctuate more frequently.

Initially, green power marketers in competitive markets were often forced to offer existing renewables because of a lack of "new" renewable energy supplies, but most marketers now offer primarily new renewables. In 2008 , about $85 \%$ of competitive-market and REC sales were supplied from new renewable energy sources. This movement toward increased reliance on new renewables has also been encouraged by green power product certification programs, which set standards for product quality, and have required increasing amounts of "new" renewables. Beginning January 1, 2007, the Green-e Energy certification program began requiring that all certified products be supplied exclusively from "new" renewable energy projects. ${ }^{24}$ Similarly, the U.S. Environmental Protection Agency's (EPA) Green Power Partnership requires its partners to purchase "new" renewables to meet its purchase criteria. ${ }^{25}$ Both Green-e and EPA define "new" as those facilities put into service on or after January 1, 1997, which is generally considered to be the inception of the voluntary green power market.

The price premium charged for competitive-market products depends on several factors including the price of standard offer or default service, the availability of incentives to green power marketers or suppliers, and the cost of renewable energy generation available in the regional market. Some marketers have charged prices close to or even below the default market price in recent years (e.g., in Texas); others have offered fixed-price products, providing customers with protection against increasing prices for a specified period of time, usually one year.

Competitively marketed green power products generally carry a price premium of between $1 \notin / \mathrm{kWh}$ and $2.5 \notin / \mathrm{kWh}$ for residential and small commercial customers, although offerings have ranged from small discounts to a premium of about $10 \phi / \mathrm{kWh}$ in recent years. In addition, price premiums can change frequently with changes in market conditions. Higher-priced products often contain a larger fraction of "new" renewable energy content or resources that are more desirable to consumers, such as new wind and solar.

Similar to competitively marketed products, retail prices charged for REC products typically range from about $1 \notin / \mathrm{kWh}$ to $2.5 \notin / \mathrm{kWh}$ for residential and small commercial customers, although some are priced as high as $5.5 \mathrm{c} / \mathrm{kWh}$. In most cases, larger customers are able to negotiate lower

\footnotetext{
${ }^{24}$ Administered by the San Francisco-based Center for Resource Solutions, the Green-e Energy program certifies retail and wholesale green power products that meet its environmental, product content, and marketing standards. For details on the Green-e Energy National Standard, see the Green-e Web site at: http://www.green-e.org/.

${ }^{25}$ See the EPA's Green Power Web site at: http://www.epa.gov/greenpower.
} 
prices. Nearly all REC products are sourced from new renewable energy generation projects as a result of product certification requirements.

REC buyers often seek certification out of concerns over "double counting" and to ensure a level of oversight and auditing because RECs are generally not subject to the same regulatory scrutiny as electricity and mandatory renewable requirements. Table 13 shows Green-e Energy certified retail transactions in 2007 and 2008. Green-e Energy certified more than 13 billion kWh of retail transactions in 2008. Compared to NREL's total voluntary market retail sales figure of 24 billion kWh, Green-e Energy certified 54\% of voluntary market retail sales (Karelas 2009).

Table 13. Total Retail Sales of Green-e Energy Certified Renewable Energy, 2007 and 2008 (Million kWh)

\begin{tabular}{|l|c|c|c|c|c|c|}
\hline & \multicolumn{2}{|c|}{ Residential } & \multicolumn{2}{c|}{ Commercial } & \multicolumn{2}{c|}{ Total Retail } \\
\hline Year & $\mathbf{2 0 0 7}$ & $\mathbf{2 0 0 8}$ & $\mathbf{2 0 0 7}$ & $\mathbf{2 0 0 8}$ & $\mathbf{2 0 0 7}$ & $\mathbf{2 0 0 8}$ \\
\hline RECs & 82 & 50 & 7,305 & 10,490 & 7,387 & 10,540 \\
\hline Green Pricing & 834 & 1,413 & 367 & 753 & 1,201 & 2,166 \\
\hline Competitive Electricity & 148 & 171 & 250 & 170 & 398 & 341 \\
\hline Total & 1,064 & 1,634 & 7,922 & 11,413 & 8,986 & 13,047 \\
\hline
\end{tabular}

Source: Karelas 2009

The Green-e Energy program also certifies wholesale renewable energy transactions, which exceeded 13 billion $\mathrm{kWh}$ in 2008. It is important to note that 8.2 billion $\mathrm{kWh}$ sold in certified wholesale transactions were resold in Green-e Energy certified retail transactions. The remaining 4.9 billion kWh were sold in non-Green-e Energy certified transactions, most likely to utilities and electric service providers, power marketers, or retail customers.

Removing the instances of renewable energy certified by Green-e Energy at both the wholesale and retail levels, Green-e Energy certified sales of 17.4 billion unique kilowatt-hours in 2008. This is an increase of $49 \%$ from 2007. Assuming that all kilowatt-hours certified at the wholesale level were ultimately sold in retail voluntary sales, $74 \%$ of the total kilowatt-hours sold in the retail voluntary market in 2008 were involved in a Green-e Energy certified transaction at some point in their chain of custody.

\section{REC and Competitive-Market Customer Participation}

Based on data received from green power marketers, we estimate that nearly 425,000 retail customers were buying green power from competitive suppliers or as unbundled RECs at the end of 2008 (Table 14). This number includes nearly 122,000 participants in utility/marketer programs available in competitive markets. Participation in utility/marketer partnership programs in competitive markets has doubled since 2005, although the number of customers remained relatively constant between year-end 2007 and 2008. Figure 5 shows growth both in sales and customer participation in utility/marketer programs in competitive markets. Between 2005 and 2007, sales and customer growth rates were nearly equivalent; but, in 2008, customer numbers grew by only $4 \%$ compared to $35 \%$ growth in sales. 


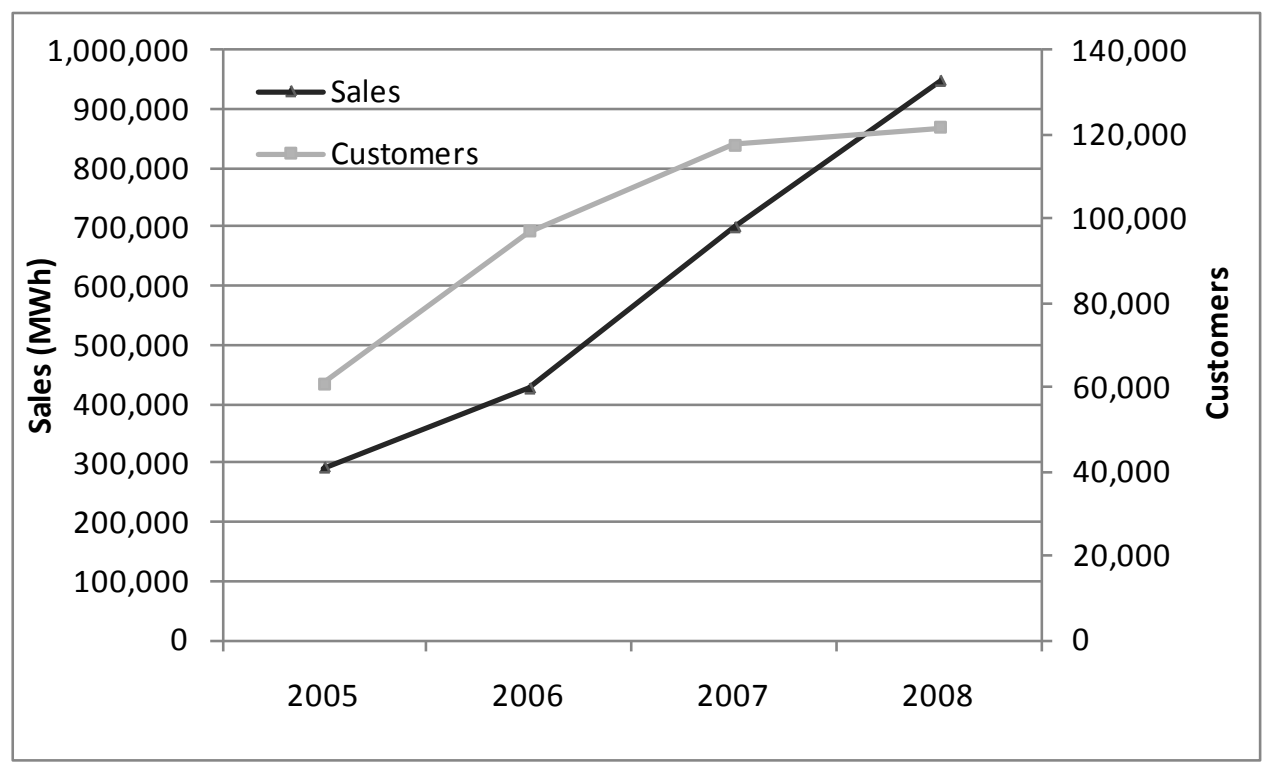

Figure 5. Growth in retail sales and customer participation for utility/marketer partnerships in competitive markets, 2005-2008

In competitive markets, the vast majority of customers buying green power are residential customers. Of the approximately 425,000 retail customers in competitive markets, fewer than $10 \%$ purchase REC-only products. The number of REC-only buyers increased from about 13,000 to 30,000 customers in 2008, showing some increase in traction with residential consumers-but the fraction of overall customers in the market is still quite small. The reason for the increase in residential REC purchasers is unknown, but could be a result of more targeted efforts to market RECs to residential consumers in some regions. While most of the REC buyers are residential customers, the majority of REC sales on a kilowatt-hour basis are made to nonresidential customers due to the much larger purchase sizes.

Table 14. Estimated Cumulative Number of Customers Buying RECs or Green Power from Competitive Marketers, 2003-2008

\begin{tabular}{|l|c|c|c|c|c|c|}
\hline & $\mathbf{2 0 0 3}$ & $\mathbf{2 0 0 4}$ & $\mathbf{2 0 0 5}$ & $\mathbf{2 0 0 6}$ & $\mathbf{2 0 0 7}$ & $\mathbf{2 0 0 8}$ \\
\hline Competitive Markets & $\sim 170,000$ & $<140,000$ & $>180,000$ & $\sim 210,000$ & $\sim 300,000$ & $\sim 390,000$ \\
\hline RECs & $* 10,000$ & $<10,000$ & $<10,000$ & $\sim 10,000$ & $\sim 13,000$ & $\sim 30,000$ \\
\hline Total & $\sim \mathbf{1 8 0 , 0 0 0}$ & $<150,000$ & $\sim 190,000$ & $\sim \mathbf{2 2 0 , 0 0 0}$ & $>\mathbf{3 1 0 , 0 0 0}$ & $\sim \mathbf{4 2 5 , 0 0 0}$ \\
\hline$\%$ Change & $13 \%$ & $-17 \%$ & $27 \%$ & $16 \%$ & $37 \%$ & $37 \%$ \\
\hline
\end{tabular}

*Includes only end-use customers purchasing RECs separate from electricity. Note: Totals may not add due to rounding.

In recent years, most of the customer gains in competitive markets resulted from utility/marketer partnership programs in the Northeast as well as customers who switched from default service to retail green power providers in a few states, most notably Texas. These gains have been tempered by losses in some states, where marketers have struggled to provide electricity service to consumers amidst adverse market conditions and increasing costs. During 2007, EIA data 
show declines in the number of green power customers in Virginia but gains in Texas, Maryland, Pennsylvania, and Washington, D.C (see Appendix C).

\section{REC and Competitive-Market Green Power Sales}

An estimated 19.5 billion $\mathrm{kWh}$ of renewable energy was sold to retail customers by competitive green power and REC marketers in 2008 (Table 15). This figure includes renewable energy from both pre-existing and new sources. In 2008 , about $85 \%$ of the REC and green power competitive-market retail kilowatt-hour sales were supplied from new renewable energy sources.

An estimated 3.9 billion $\mathrm{kWh}$ were sold as a bundled green power product in competitive electricity markets - more than a $20 \%$ increase from 2007 . The competitive-market sales figure includes renewable energy sales through default utility/marketer programs or individual utility/marketer partnerships in competitive markets, which amounted to approximately 950 million kWh in 2008, a 35\% increase from 2007 (see Figure 5). Retail REC sales increased by nearly $50 \%$, reaching 15.6 billion $\mathrm{kWh}$ in 2008. Most of the growth in REC-only sales is attributable to the nonresidential sector.

Table 15. Retail Sales of Renewable Energy in Competitive Markets and RECs* (Million kWh), 2004-2008

\begin{tabular}{|c|c|c|c|c|c|}
\hline & 2004 & 2005 & 2006 & 2007 & 2008 \\
\hline \multicolumn{6}{|c|}{ Competitive Markets } \\
\hline Residential & 2,140 & 1,330 & 1,000 & 1,800 & 2,700 \\
\hline Nonresidential & 510 & 820 & 710 & 1,400 & 1,200 \\
\hline Subtotal & 2,650 & 2,150 & $1,720^{* *}$ & 3,200 & 3,900 \\
\hline$\%$ Change & $40 \%$ & $-19 \%$ & $-20 \%$ ** & $88 \%$ ** & $22 \%$ \\
\hline$\%$ Residential & $81 \%$ & $62 \%$ & $59 \%$ & $56 \%$ & $69 \%$ \\
\hline \multicolumn{6}{|c|}{ Unbundled RECs $\mathbf{s}^{* * *}$} \\
\hline Residential & 40 & 40 & 110 & 60 & 200 \\
\hline Nonresidential & 1,690 & 3,840 & 6,700 & 10,500 & 15,400 \\
\hline Subtotal & 1,720 & 3,890 & 6,810 & 10,500 & 15,600 \\
\hline$\%$ Change & $160 \%$ & $126 \%$ & $75 \%$ & $55 \%$ & $49 \%$ \\
\hline$\%$ Residential & $2 \%$ & $1 \%$ & $2 \%$ & $1 \%$ & $1 \%$ \\
\hline Total Sales & 4,370 & 6,040 & 8,530 & 13,800 & 19,500 \\
\hline$\%$ Change & $71 \%$ & $38 \%$ & $41 \%$ & $62 \%$ & $41 \%$ \\
\hline
\end{tabular}

*Totals may not add due to rounding.

${ }^{* *} 2006$ are likely underestimated because of data gaps.

***Includes only RECs sold to end-use customers separate from electricity.

Table 15 also delineates green power sales by customer segment. In 2008, residential customers represented more than two-thirds of green power sales in competitive markets. In contrast, nonresidential customers represented nearly all unbundled REC sales. Generally, nonresidential customers find REC-only products attractive because of their flexibility and the greater potential 
for cost savings because they can be sourced from renewable energy projects in more favorable resource locations; also, the electricity does not have to be delivered directly to the customer, which lowers transaction costs. On the other hand, residential customers may not be aware that RECs are available or may not understand them. As noted above, the slight uptick in residential REC purchasers in 2008 may have resulted from more targeted efforts to market RECs to residential customers in some regions; however, the actual cause of the increase is not known. For commercial and institutional customers that operate facilities in multiple locations across the country, RECs may also provide a more efficient green power sourcing solution than working with utilities in each individual utility territory. ${ }^{26}$

In 2008, renewable energy sold in competitive markets or as unbundled RECs represented an equivalent renewable energy capacity of nearly 5,800 MW, with almost 4,900 MW of this total coming from "new" renewable energy resources (Table 16). This is up from 3,700 MW of equivalent capacity and 3,000 MW of new capacity in 2007. Equivalent figures for 2006 are 2,400 MW and 2,100 MW, respectively. Capacity estimates for earlier years are provided in Table 4 and Appendix A.

Table 16. Renewable Energy Sources Supplying Competitive and REC Markets, 2008

\begin{tabular}{|l|c|c|c|c|c|c|c|}
\hline & $\begin{array}{c}\text { Biomass/ } \\
\text { Landfill Gas }\end{array}$ & $\begin{array}{c}\text { Geo- } \\
\text { thermal }\end{array}$ & Hydro & Solar & Wind & Unknown & Total \\
\hline MWh Sales & $3,697,000$ & 345,000 & $2,124,000$ & 23,000 & $13,293,000$ & 44,000 & $19,526,000$ \\
\hline$\%$ of Total Sales & $19 \%$ & $2 \%$ & $11 \%$ & $0.12 \%$ & $68 \%$ & $<1 \%$ & $100 \%$ \\
\hline Total MW & $\mathbf{5 0 0}$ & $\mathbf{4 0}$ & $\mathbf{6 1 0}$ & $\mathbf{2 0}$ & $\mathbf{4 , 5 9 0}$ & $\mathbf{1 0}$ & $\mathbf{5 , 7 7 0}$ \\
\hline MW New RE & $\mathbf{4 2 0}$ & $\mathbf{3}$ & $\mathbf{1 3 0}$ & $\mathbf{2 0}$ & $\mathbf{4 , 2 7 0}$ & $-\mathbf{4}$ & $\mathbf{4 , 8 6 0}$ \\
\hline
\end{tabular}

Information on new content is unavailable in some instances.

\footnotetext{
${ }^{26}$ For example, the EPA Green Power Partnership reports that the majority of its Top 25 partners purchase RECs (Appendix B), see http://www.epa.gov/greenpower/. In addition, the Green Power Market Development Group promotes the purchase of RECs among its members, see the organization's Web site at: http://www.thegreenpowergroup.org/.
} 


\section{The Voluntary Carbon Offsets Market}

Green power markets are affected by other related markets, such as the emerging U.S. market for greenhouse gas (GHG) offsets. Because green power and GHG offset markets have converged in recent years, this section addresses GHG offsets sourced from renewables. A GHG offset (sometimes referred to as a carbon offset) is a tradable commodity representing a unit of GHG emissions reduction or avoidance - typically, one metric ton of carbon dioxide equivalent $\left(\mathrm{CO}_{2} \mathrm{e}\right)$. Corporations and individuals are buying these products to "offset" their own emissions, such as those associated with energy used for heating, product manufacturing processes, automobile use, and air travel.

GHG offsets can be derived from a variety of project types that reduce or avoid GHG emissions, which use diverse methods for measuring these reductions. Examples of GHG reduction projects include renewable electricity generation, energy efficiency measures, methane capture at landfill sites, soil carbon sequestration, and forestry projects. Developers of these project types can sell GHG offsets to consumers or businesses to help finance their projects. For GHG offsets sourced from renewable energy generation projects, the equivalent emissions reduction of replacing conventional generation with renewable generation must be calculated. More than 25 companies offer offset products derived at least, in part, from renewable energy generation projects. ${ }^{27}$

Offsets sourced from renewable energy differ from green power in that they are sold in tons of $\mathrm{CO}_{2} \mathrm{e}$, while RECs and other forms of green power are sold in kilowatt-hours. In addition, certification standards for offsets differ from those for renewable energy and not all RECs can be converted to offsets. Generally, offsets must demonstrate additionality, meaning that the emissions reductions are additional to what would have occurred anyway (or under business as usual). Retail customers typically purchase green power or RECs equivalent to a portion or all of their electricity consumption. In contrast, retail customers buying GHG offsets generally purchase tons of $\mathrm{CO}_{2} \mathrm{e}$ to match their carbon emissions. There is overlap in the sense that many green power purchasers are motivated to buy green power for their electricity consumption out of concern about climate change and to address their electricity-related GHG emissions. Currently, renewable energy could provide either a GHG offset (ton of $\mathrm{CO}_{2}$ ) or a kilowatt-hour of green power-however; there are double-counting concerns if the same kilowatt-hour is sold as both an offset and a REC. Certifiers generally do no allow this type of double counting.

Eight out of approximately $20 \mathrm{GHG}$ offset providers that offer products at least partially sourced from U.S.-based renewable generation reported 2008 offset sales to NREL. The carbon offsets sourced from renewables totaled nearly 250,000 metric tons of $\mathrm{CO}_{2}$ equivalent, which is equivalent to about $340,000 \mathrm{MWh}$ of renewable energy generation. ${ }^{28}$

\footnotetext{
${ }^{27}$ The Green Power Network tracks GHG offset providers and products that are available nationally and are derived at least in part from U.S.-based renewable energy generation projects

${ }^{28}$ The EPA's national average electricity emissions factor for nonbaseload generation (eGRID 2009) was used to estimate the equivalent in MWh.
} 
Table 17. GHG Offsets Sourced from U.S.-Based Renewable Energy Sources, 2008

\begin{tabular}{|l|r|r|}
\hline & $\begin{array}{c}\text { Metric Tons } \\
\text { CO2e }\end{array}$ & $\begin{array}{c}\text { Equivalent } \\
\text { in } \mathbf{M W h}\end{array}$ \\
\hline Residential & 31,200 & 43,500 \\
\hline Non Residential & 214,700 & 299,000 \\
\hline Total & $\mathbf{2 4 5 , 9 0 0}$ & $\mathbf{3 4 2 , 5 0 0}$ \\
\hline
\end{tabular}

Several independent certifiers have created standards for verifying emissions GHG reductions to ensure that they are real, measurable, and beyond business as usual and any regulatory requirement. They also establish ownership of the actual emission reductions so that multiple parties do not claim the carbon reduction. GHG offset providers responding to the NREL questionnaire reported that some, if not all, of their offsets were verified by the following organizations: Center for Resource Solutions, ${ }^{29}$ Environmental Resources Trust, ${ }^{30}$ or the Chicago Climate Exchange (CCX). ${ }^{31}$

Proposed federal or regional cap and trade programs have the potential to impact the ability for renewables located within capped regions to provide GHG offsets once emissions caps take effect, depending on program design details. Because renewables provide indirect emissions reductions by displacing emissions from fossil fuel generators, they may not have a claim to the emissions reductions under a cap and trade program, unless provisions such as allowance set asides are adopted. The Regional Greenhouse Gas Initiative in the Northeast, the only cap currently in effect in the U.S., includes a voluntary renewable energy set aside through which states retire $\mathrm{CO} 2$ allowances on behalf of voluntary renewable energy purchases, ensuring emission reductions associated with the renewable generation.

\footnotetext{
${ }^{29}$ In February 2008, the Center for Resource Solutions certified its first retail products under Green-e Climate, a consumer-protection program requiring verification of GHG reductions based on a project-level certification program that ensures the reductions have taken place, are permanent, and come from projects that would not have happened under a "business-as-usual" scenario. Sellers must undergo a yearly audit to ensure their supply of offsets matches their sales, and comply with Green-e Climate's consumer-disclosure and truth in advertising requirements. The Green-e Climate Protocol for Renewable Energy requires that GHG emissions reductions from renewable energy must meet all the Green-e Climate verification standards as well as additionality requirements to ensure that they are beyond business as usual. The protocol requires that the RECs associated with the renewable energy generation certified under Green-e Climate be retired and not resold in the voluntary green power markets or used for compliance with renewable energy standards. The generator and/or seller must verify that the attributes are only sold once, and not double counted. For more information, see the protocol at http://www.greene.org/docs/climate/Green-e_Climate_Protocol_for_RE.pdf.

${ }_{30}^{30}$ The Environmental Resource Trust/Winrock International verifies carbon offsets in partnership with the American Carbon Registry. The American Carbon Registry allows flexibility for members to choose among methodologies set out by the Clean Development Mechanism (CDM) and the Voluntary Carbon Standard (VCS). A carbon offset is considered an emissions reduction ton (ERT) if it is real, additional, permanent, and that ownership is incontestable. After verification, the Registry assigns each offset a unique serial number. For more information on the ERT certification, see http://www.winrock.org/common/files/Solution_Stories/acr_capabilities.pdf.

${ }^{31}$ The Chicago Climate Exchange guidelines for carbon offsets sourced from renewable energy generation were established in 2006. To qualify, RE systems must have been activated on or after January 1, 2005. Project proponents must demonstrate ownership rights associated with the environmental attributes, (i.e. must not have sold the RECs, or used them for compliance purposes). Under the verification process, for CCX Offsets to be issued, the RECs are surrendered to and retired by CCX. For more information on the CCX guidelines, see http://www.chicagoclimatex.com/news/publications/pdf/CCX_Renewable_Offsets.pdf
} 


\section{Voluntary Green Power Market Trends and Issues}

As the voluntary green power market continues to grow, a few trends and issues have surfaced. This section explores the appropriate level of marketing costs for utility green pricing programs, highlights trends in REC prices in both the compliance and voluntary markets, and explores the future role of the voluntary market as compliance markets expand.

\section{Program Marketing Expenditures: Finding the Right Balance}

In 2008, some market observers raised concerns about optimal levels of spending for marketing green pricing programs. As a percentage of program revenues, programs spent a median of $18.8 \%$ on marketing their program in 2008 and $16.6 \%$ in 2007 , with the smallest utilities (with less than 25,000 in their eligible customer base) spending $49 \%$ of revenues, significantly more than the overall median. Figure 6 shows 2008 marketing and administration expenditures by utility size. $^{32}$

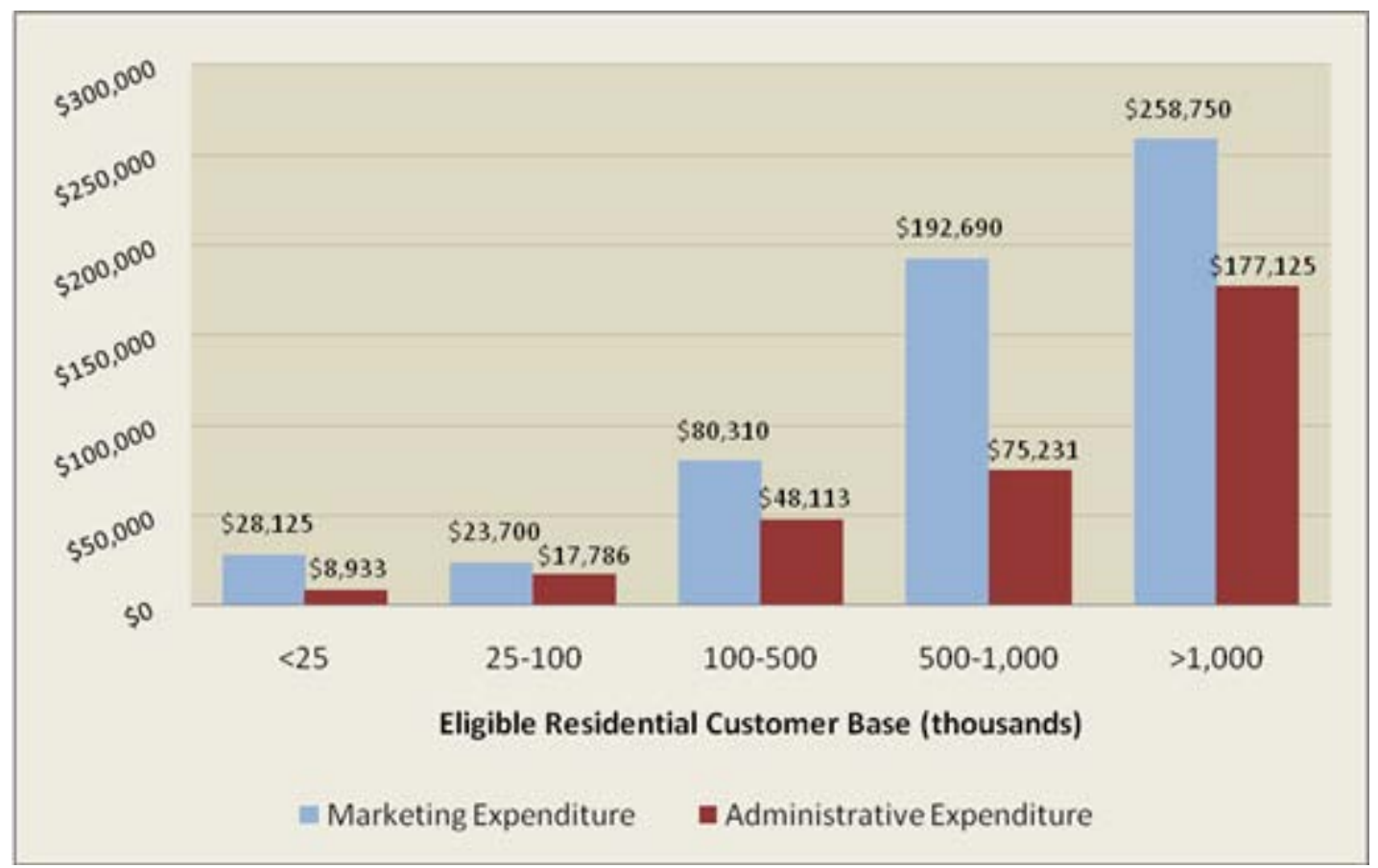

Figure 6. Average program marketing and administration expenditures (2008), by utility size

\footnotetext{
${ }^{32}$ Some caveats must be understood with respect to these data. Programs' data collection methods and proficiency tend to be inconsistent. There is no single set of accounting definitions to which programs adhere. Some programs do not collect these data at all, and some collect but do not report it to NREL. In addition, there is likely an inherent "survivorship" bias, or tendency for programs to under-report data showing poor results or high acquisition costs. Several programs either have no budgets or rely on broader utility marketing budgets for some or all of their marketing expenditures and/or labor costs. In such cases, these costs are paid for by all ratepayers rather than solely by program participants, resulting in a lower reported expenditure. The recent increased scrutiny on these data suggests improving and standardizing accounting and collection practices.
} 
Budgets for marketing and administration of green pricing programs are a function of several factors: the region of the country; the size of the utility service area; the customer base and media markets encompassed within that service area; the point or stage in the lifespan of the program; and certainly, not least, the utility's commitment to and goals for the program. All of these factors vary significantly among programs.

Conclusions about what might be the optimal level of program expenditures for marketing often rest on whether such expenditures are framed as consumer education in the public interest. As in many businesses, programs must balance investing in consumer education, expanding program participation, keeping participation affordable, and maintaining standards for product quality and supporting new renewable energy development. These goals are not mutually exclusive; strong marketing has been shown to support robust participation, which can enable a program to support more new renewable energy projects. How a program strategy is designed depends on what the strategy is meant to accomplish. Some utilities have comprehensive environmental goals or goals intended to green their brand. Other utilities aim only to make a renewable option available to customers and spend little or nothing on marketing.

While program experience has shown that marketing expenditures are important for program growth, the question of the optimal amount of marketing expenditures has arisen largely in the context of product quality, specifically around the perception that participant dollars could be better put to use through greater investment in more new renewable capacity than in marketing. Yet active marketing need not come at the expense of product quality - spending more to attract more participation can instead grow the size of the market and result in more new development.

Like any new business, some programs tend to spend more on marketing in their "start-up" phase (the first two to three years of a new program), during which time the program feels its greatest burden to educate customers about the new offering and entice them to enroll. Even those that do not spend significantly more on marketing in early years subsequently spend less as a percentage of revenues over time, simply because their revenues tend to increase over time. Like any business, the start-up phase is a relatively costly investment for which programs sometimes do not see a return for several years.

In the start-up phase of a business - which can be a different length of time for different industries - the new business has a disproportionate need to spend money on several cost components that tend to lessen in subsequent years. These include the following:

- Hiring and training staff and call center representatives

- Conducting market research

- Developing a business plan and designing the program

- Establishing a brand and building product awareness

- Identifying the target market and message

- Building a Web site

- Identifying and purchasing wholesale products

- Developing and creating marketing materials

- Establishing mechanisms for billing and for processing sales. 
On the other hand, it can become more costly to attract customers in the later years in the life of a program, after the "low-hanging fruit" - the customers most inclined to sign up - are already enrolled. In this later phase, some programs engage in more expensive marketing tactics, such as direct mail or telemarketing. Program managers might do this for a combination of reasons. For example, they might conclude that the less expensive bill inserts or bangtails have accomplished what they can, they could be limited in the number of bill inserts that their program can use because of competition from other internal utility programs, or they might tailor specific messages to residential customer segments that have been less inclined to participate. As a result, marketing costs could increase again in the later years of a program.

The question of program marketing expenditures inevitably leads to broader issues of program transparency, the value customers are receiving for their premium, and the question of how well the expenditures are accomplishing their stated goals. On the question of transparency, the Green-e Energy certification program, which has become the leading certification standard for green pricing programs, does not require public disclosure of the renewable energy projects supported by a green pricing program, or disclosure of the budgets or breakout data on program expenditures. However, some consumer advocates have said that a "best practice" standard should include project disclosure, contending that consumers have a right to know which projects their premiums are supporting.

To better understand recent concerns about marketing costs, particularly among investor-owned utilities, it is useful to view current issues in light of the original impetus for green pricing. The first programs were launched in the mid- to late 1990s during the movement toward retail electricity restructuring and its concomitant emphasis on customer choice. Green pricing programs were by design the first, and they remain the only, non-price-based differentiator for electricity commodity. They are the only option for customers to choose electricity not as a commodity but as a product reflecting customer values.

Yet from the outset, customer confusion about the new product made consumer education a necessary element to the success of green pricing programs. Such educational efforts, and the increased costs associated with them relative to other utility programs, have been supported by some regulators as squarely within the public interest. This is primarily because of the product's promise as a solution to environmental and other public concerns, and the notion of the public's interest in having a value-based choice in their energy supply.

\section{Product or Donation: Why has the question of marketing expenditures arisen?}

It is unusual for the level of a private, unregulated for-profit company's marketing expenditures to be questioned, although charities may face such questions. One would assume that a company has incentive to spend only the amount of money justified by the expected return on that expenditure, so that the free market can be trusted because of these built-in incentives. But energy is a regulated industry, and regulators are charged with protecting customer value. In addition, green pricing programs bear similarities to charitable organizations and may well be facing more scrutiny because of those similarities. In fact, some utilities have marketed programs 
as charitable contributions which, in some cases, are tax-deductible. ${ }^{33}$ However, the industry has more typically framed green power conceptually as a "product," a quantity of renewable energy that matches all or part of consumers' electricity consumption. Of the more than 850 U.S. green pricing programs, about 15-20 call themselves "contribution" programs. ${ }^{34}$

Unlike private businesses, charitable organizations' value is evaluated in part on how little they spend on marketing and administration. The question is asked far less of for-profit companies. And, in the case of green pricing programs, if more marketing expenditure results in greater demand for renewable energy or in greater program participation, should that reduce the importance of the question of how much was spent on marketing? In determining optimal levels for programs to spend on marketing, it is helpful to appreciate the ambiguity in the nature of the green pricing product and premium. Is the premium a payment for a product or a donation supporting a cause? Customers are purchasing a product, in that in the vast majority of programs, they are paying for a specific quantity of renewable energy to match their electricity consumption. Yet green pricing programs bear important similarities to charities. The comparison of green pricing programs to charities is made for several reasons. Perhaps the most important is the similarity in messaging, with its emphasis on doing the right thing, "making a difference," and the legacy message with a call to action for future generations and for the environment. Similar to charitable organizations, green pricing programs typically craft "cause marketing" messages that resemble a request for a donation in that an appeal is made to make a difference or do the right thing. Typical examples of marketing claims and calls to action in green pricing marketing materials include the following:

- a...way to support our environment.

- leaving our family a brighter future.

- develop new renewable energy resources.

- make an impact...on the environment.

In addition to the messaging similarities to "cause" marketing, there is a question regarding the green power product itself: Because it has no tangible personal benefit or, at the very least, the benefit is primarily public, can it be said that those "buying" it are buying a product? The similarity to charitable causes is an important one in the context of marketing expenditures, because it is only in this similarity that the question has been asked in the first place; companies selling products and services are rarely, if ever, scrutinized on this basis. In their 2008 case before the Florida Public Service Commission, Green Mountain Energy Company raised the applicability of the question, as follows:

"[A] utility company might contract with a local General Motors dealer to purchase a fleet of trucks. The utility pays the dealer the agreed-upon price... After the dealer has covered the cost of purchasing and delivering the trucks, any revenue left over from the purchase price belongs to the dealer. Any inquiry into the dealer's advertising, selling or other costs is inappropriate and demonstrates a misunderstanding of the legal and economic basis of the relationship between the dealer and FPL."

\footnotetext{
${ }^{33}$ For example, NC Greenpower, a program which is offered to utility customers throughout North Carolina, offers tax deductions for "contributions" to the green power program. For more information, see http://www.ncgreenpower.org/signup/online contributions.html.

${ }^{34}$ For more information, see greenpower.energy.gov.
} 
The green pricing premium could be compared to a donation to public radio, where consumers and businesses "buy" the product for their neighbors, not just for themselves; they pay for a service they are receiving and for a public good at the same time. On the other hand, because green pricing participants are receiving a product tied to specific quantities based on the amount of energy they use, the purchase could also be seen as more akin to a product purchase than a charitable donation - in these cases, people generally donate money based on what they can afford or wish to contribute.

Energy-based green pricing programs can be distinguished from charities on the basis of the specific amount of energy delivered to the grid. When making a charitable contribution, donors give what they can afford in expectation that the beneficiary will put their contribution to "good use." The efficacy of the charity is judged in part on the portion of the donation spent on the "cause." This ratio is not always known at the time the donation is solicited. In addition, because some companies now use renewable energy to claim emissions reductions, it is important to understand that such claims are made on the basis of a purchase of renewable energy, as distinguished from a donation.

In contrast, an energy-based green pricing program typically offers a firm quantity of renewable energy at a firm price. The price, terms, and conditions are disclosed in standardized language in most cases and always in the case of Green-e Energy certified programs. For example, when programs offer a $100 \%$ usage option, if a customer on average uses $1,000 \mathrm{kWh}$ per month and the offered green premium is 1.5 cents per $\mathrm{kWh}$, then the consumer can be confident that the enrollment will result in $1,000 \mathrm{kWh}$ of renewable energy being added to the grid at a cost of $\$ 15$ per month added to their bill. The customer can evaluate whether they perceive the offering to be a good value.

In the final analysis, it is only in considering the hybrid nature of voluntary programs that a balanced assessment of "how much is too much" marketing costs can be made. Furthermore, there is no clear optimal level of marketing expenditure; rather, appropriate costs may vary by type of program, customer base, age of program, and a variety of other factors. 


\section{Renewable Energy Certificate Prices}

This section provides an overview of wholesale REC prices in voluntary and compliance markets in recent years based on indicative data available from brokers and third-party data providers. With a few exceptions, there is little price transparency in REC markets. Most transactions are conducted as bilateral contracts between parties, and prices are not reported. In addition, prices can vary widely by region. Therefore, data presented here are only indicative and should be used with caution.

In general, REC values depend on a number of factors, including whether the RECs are bought to meet compliance obligations or serve voluntary retail consumers, the technology, the vintage (year in which it was generated), the volume purchased, whether they are eligible for certification, and the region in which the generator is located.

The region from which RECs are sourced is particularly important because often there are regional differences in renewable energy resource quality (i.e., wind speed) and electricity prices that determine the cost-effectiveness of the renewable generation. In addition, the supply and demand of RECs often varies regionally. In regions where there have been shortages of renewables to meet RPS requirements, REC prices have reached or come near to levels for alternative compliance payment (ACP) of $\$ 50-\$ 55 / \mathrm{MWh}$; whereas, in other states or regions, compliance RECs have sold for less than $\$ 5 / \mathrm{MWh}$. Figure 7 shows the wide variation in compliance-market REC prices among states for which data are available.

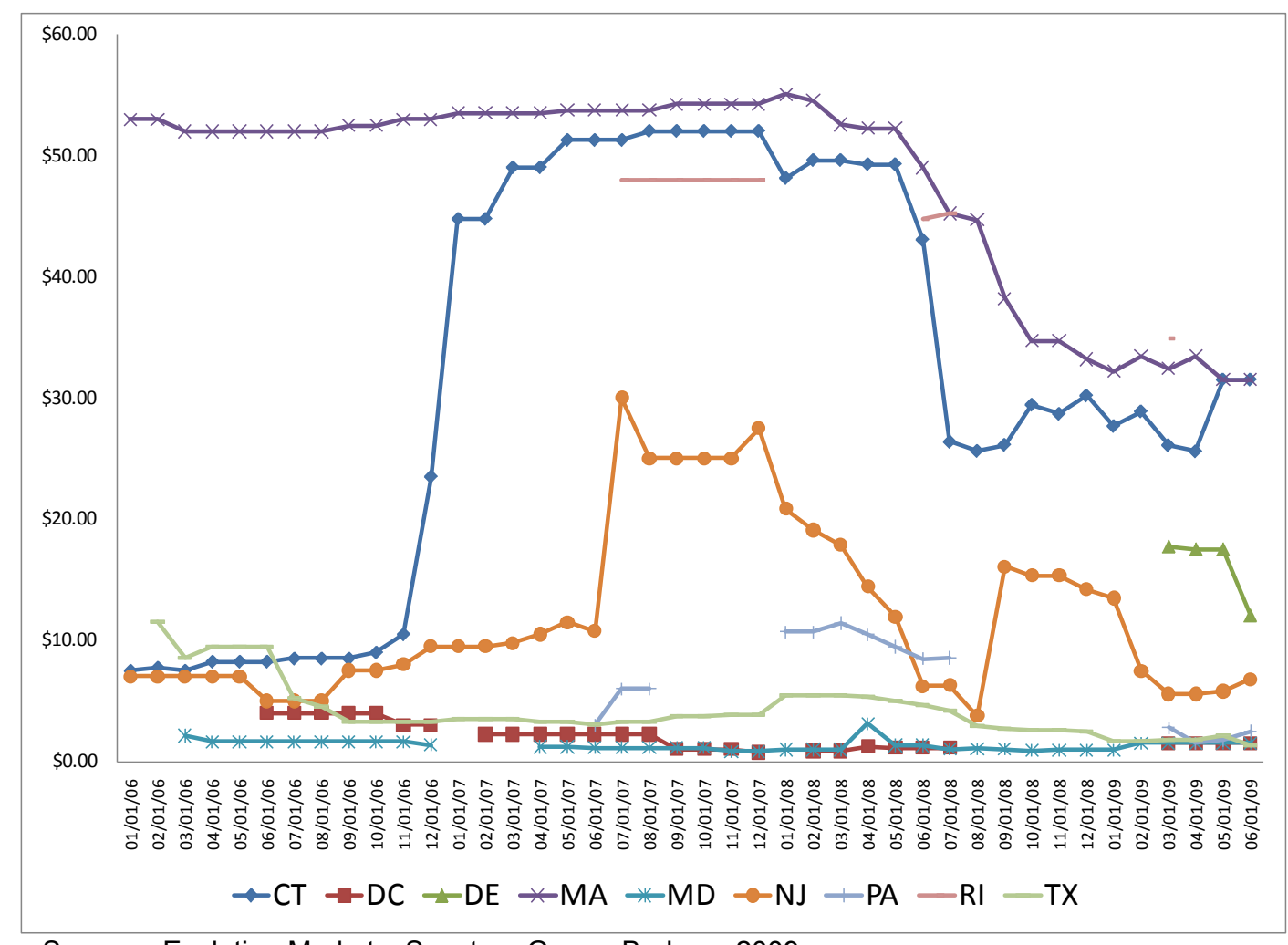

Sources: Evolution Markets, Spectron Group, Barbose 2009

Figure 7. Compliance market (primary tier) REC prices, 2006 to mid-2009 
Solar RECs (SRECs) have higher value than RECs from other resource types in both compliance and voluntary markets. This is true for a number of reasons: 1) at least 18 state RPS programs have specific provisions to encourage solar or distributed generation (DG) (DSIRE 2009e); 2) the penalty price for noncompliance is often set higher for solar/DG tiers than for standard RPS compliance; and 3) SRECs can be desirable in the voluntary market, where customers may be willing to pay more for solar, which costs more than other renewables. Data availability is limited, but several price points are indicative of the higher market price for SRECs in compliance markets in 2009 (Table 18). Figure 8 compares voluntary solar RECs to generic and wind RECs. In the first half of 2008, both voluntary solar RECs (SRECs) sourced from anywhere in the nation and those from the Western region ranged from about $\$ 7 / \mathrm{MWh}$ to \$10/MWh.

Table 18. 2009 Compliance Market SREC Prices

Source: Spectron Group 2009

\begin{tabular}{|l|c|}
\cline { 2 - 2 } \multicolumn{1}{c|}{} & Range of SREC Prices \\
\hline New Jersey & $\$ 665-\$ 685$ \\
\hline Delaware & $\$ 225-\$ 300$ \\
\hline Maryland & $\$ 350$ \\
\hline Pennsylvania & $\$ 275-\$ 315$ \\
\hline
\end{tabular}

Note: Values represent the midpoint of the bid and offer prices for current-year vintage.

While compliance RECs generally must be sourced from within some geographic region to be eligible for RPS compliance, voluntary RECs can be sourced either regionally or nationally. Most utility green pricing programs or marketers selling bundled electricity and REC products source their products from local or regional resources, with some exceptions. Buyers of nationally sourced RECs are often large corporations that have facilities in multiple locations across the country. In voluntary markets, RECs that are sourced locally (within the region) may have to compete with RPS demand or be subject to regional resource limitations. Therefore, regionally sourced RECs often sell at a premium to nationally sourced RECs, which are often derived from the most cost-effective renewable resources. As shown in Figure 8, wholesale RECs used in voluntary markets have generally traded in the range of $\$ 1 / \mathrm{MWh}$ to $\$ 10 / \mathrm{MWh}$, based on available indicative data. 


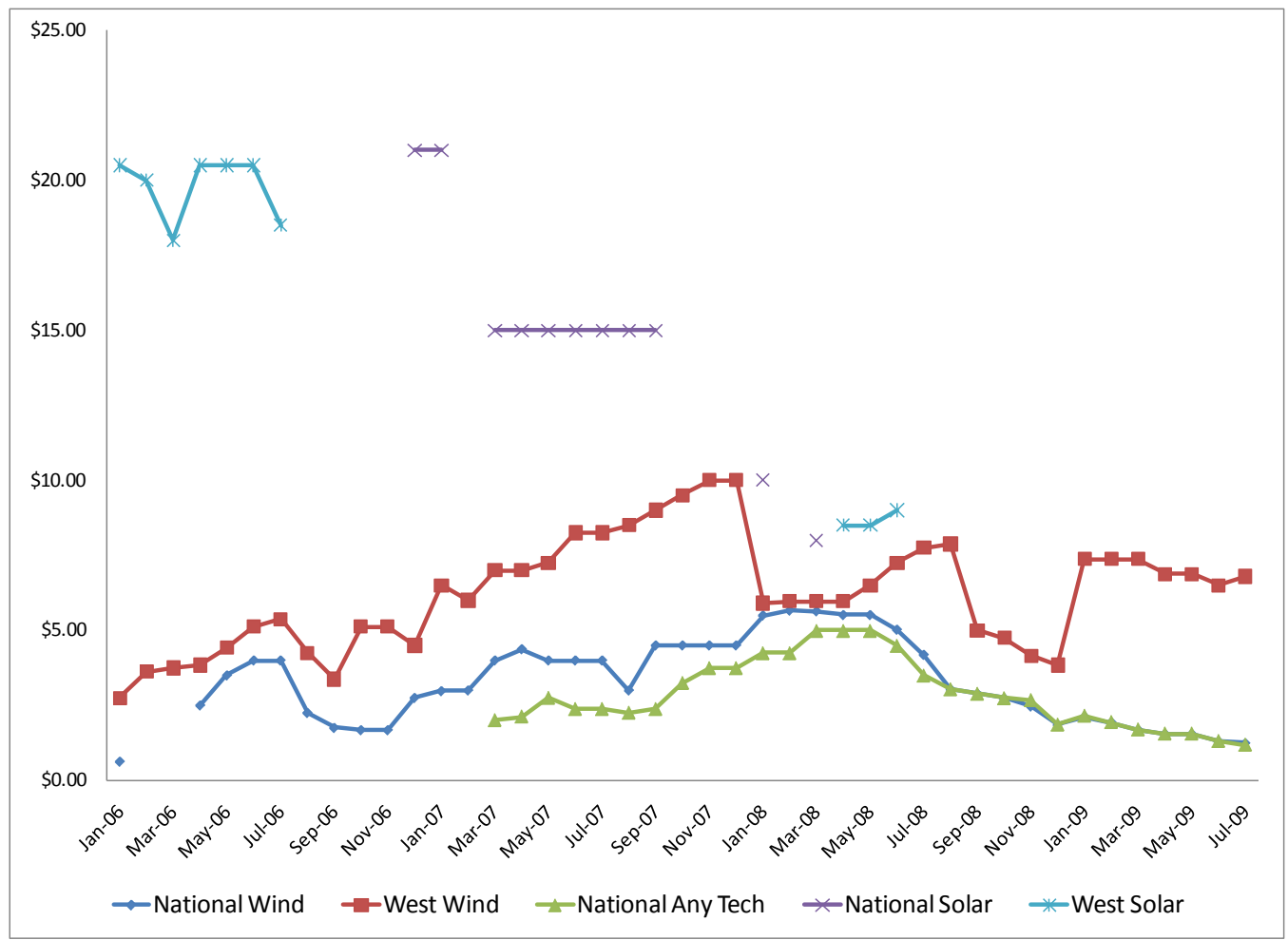

Sources: Evolution Markets, Spectron Group, Barbose 2009

Figure 8. Voluntary REC prices, 2006 to mid-2009

Table 19 presents wholesale REC prices for wind and for any renewable energy technology located nationally, as well as wind from within the Western Electric Coordinating Council (WECC). In 2008, prices paid for nationally sourced RECs from any technology ranged from about $\$ 1.50 / \mathrm{MWh}$ to $\$ 5.50 / \mathrm{MWh}$; but, in the first half of 2009 , these prices declined, ranging from about $\$ 1 / \mathrm{MWh}$ to $\$ 2 / \mathrm{MWh}$ (see Figure 8). Wind RECs, sourced both nationally and from WECC, netted higher prices, on average, than generic RECs sourced from any technology; but they also fell in late 2008. Prices differ not only by the technology and the location, but also by the vintage. Voluntary RECs sold in a given year can only be Green-e Energy certified if the renewable energy with which they are associated is generated in the calendar year in which the product is sold, the first three months of the following calendar year, or the last six months of the prior calendar year (CRS 2008). Table 19 shows price ranges for different vintages based on bids and offers in 2008 (ranges are based on the midpoint between bid and offer prices). Forward contracts for 2009 vintage RECs were sold at a slight premium during 2008.

Table 19. Range of Voluntary REC Prices in 2008 for Different Vintages (\$/MWh)

\begin{tabular}{|l|c|c|c|}
\hline Range Year & $\mathbf{2 0 0 7}$ & $\mathbf{2 0 0 8}$ & $\mathbf{2 0 0 9}$ \\
\hline National Any Technology & $\$ 1.5-\$ 4.7$ & $\$ 1.9-\$ 5.3$ & $\$ 2.7-\$ 5.5$ \\
\hline National Wind & $\$ 1.5-\$ 4.7$ & $\$ 1.9-\$ 5.7$ & $\$ 2.7-\$ 6.1$ \\
\hline WECC Wind & $\$ 2.3-\$ 6.4$ & $\$ 3.8-\$ 7.9$ & $\$ 6.1-\$ 8.6$ \\
\hline
\end{tabular}

Source: Spectron Group 2008 


\section{Regional REC Supply and Demand Balances}

As the geographic coverage and stringency of state renewable portfolio standards (RPS) increases, and in light of the debate over a federal RPS, implementers have asked whether supplies will be adequate to meet these existing policies as well as demand from voluntary purchasers. Supply shortages have occurred in some regions, which has increased prices for RECs and limited supplies available to voluntary markets in a few instances. This has caused some concern that increased demand for renewables resulting from RPS policies will outstrip supplies and increase prices for RECs in coming years.

In an attempt to shed some light on these questions, a recent NREL analysis (Bird et al. 2009) examined the balance between the demand and supply of new U.S. renewable electricity on a regional basis through 2015 . The analysis relied on estimates of renewable energy supplies compared to the demand for renewable energy generation necessary to meet existing state renewable portfolio standard (RPS) policies in 28 states as well as demand by consumers who voluntarily purchase renewable energy. ${ }^{35}$ Note that the analysis did not consider the impacts of a potential federal RPS, only policies already in place. Two supply scenarios were examined: 1) a business-as-usual (BAU) scenario based on current growth rates in renewable energy supply in each region, and 2) a market-based scenario that differs only in an assumed higher overall level of wind energy development nationally (based on estimates from BTM Consult and referred to as "high wind case").

The analysis found an overall national surplus of renewable energy generation to meet existing RPS policy targets and voluntary market demand over the study period. However, based on the assumptions in the analysis, some regional shortages were projected, as well as regions with excess supplies. Figure 9 compares the two supply scenarios to renewable energy demand from RPS policies and voluntary markets in each of the regions considered in this analysis for 2015 . It is important to note that the analysis did not take into account the effect of the global financial crisis, because of the uncertainty of the impacts.

Based on the assumptions in the analysis, deficits were projected for New England, New York, and the Mid-Atlantic areas, with notable surpluses in the Midwest, the Heartland, Texas, and the West. The BAU scenario, based on an extrapolation of recent development trends, found an internal shortfall for California; while, under the high wind energy scenario, California had excess generation except for one year (2010). The analysis did not assume trading among the regions specified in the analysis; however, in some cases, such trading may be feasible to the extent that it is not limited by transmission access or state RPS renewable energy certificate (REC) trading rules. For example, shortages in California - which is treated as an independent region in the analysis - could possibly be offset by surplus supply projected elsewhere in the West to the extent it can meet California's deliverability requirements.

\footnotetext{
${ }^{35}$ However, the analysis did not address demand by utilities that may procure cost-effective renewables through an integrated resource planning process or otherwise.
} 


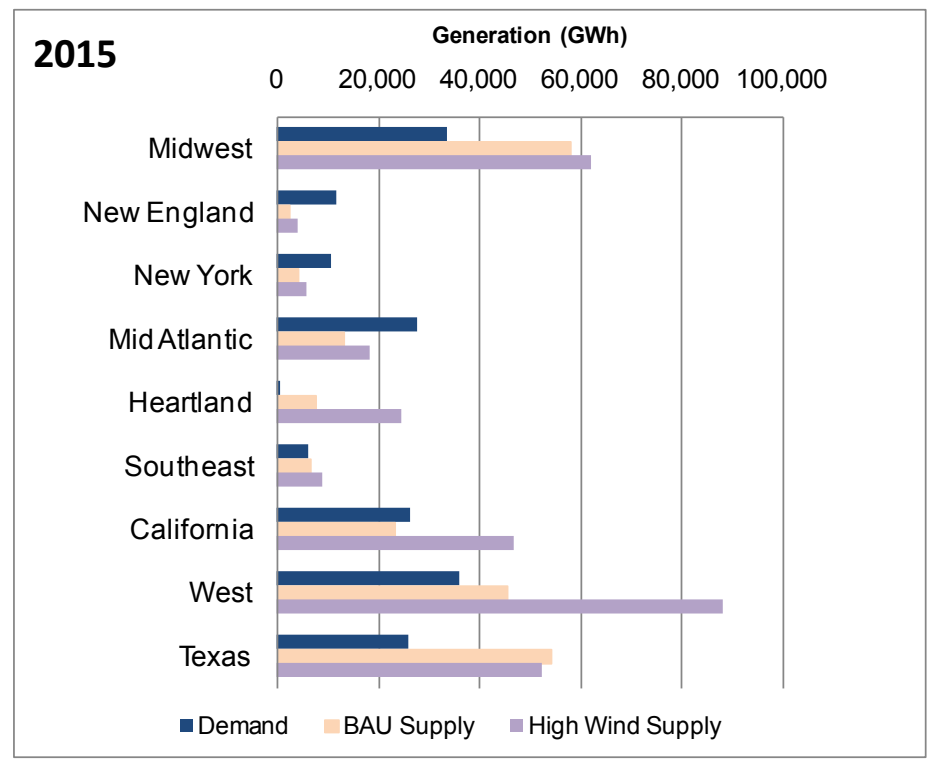

Figure 9. Snapshot of regional demand and supply under the two cases in 2015 (GWh)

In addition to interregional transfers where transmission is available, shortfalls could be addressed through price signals that may accelerate development of renewable energy resources that are currently uneconomic. This is particularly true in areas that have no or few market barriers. In areas with market barriers or transmission constraints, removing barriers to development, adding new transmission, and expanding interregional REC trading could alleviate potential regional shortfalls and enable states to access least-cost renewables. Key uncertainties in the analysis include the impact of the global financial crisis, potential changes in incentives or policies, the ability for renewable energy to access transmission, as well as the ability to develop offshore wind in the East. ${ }^{36}$

If renewable electricity shortages develop as projected in some regions by 2015 , it is likely that REC prices will increase in those regions. Higher prices could dampen voluntary demand in affected regions, and RPS demand might even outbid some existing regional voluntary demand. However, prices for nationally sourced RECs would not necessarily be affected by regional shortages - as long as a national shortage does not develop, which has been the case in the recent past.

\footnotetext{
${ }^{36}$ While the pace of development in coming years will depend on the ability of the federal government and the financial industry to address the financial crisis and increase the availability of debt for project financing, the estimates presented in the analysis did not account for potential impacts of the crisis, because they are highly uncertain.
} 


\section{Conclusions and Observations}

The green power market continues to exhibit strong growth and provide an important demanddriven stimulus for renewable energy development. Green power markets provide an additional revenue stream for renewable energy projects, and raise consumer awareness of the benefits of renewable energy. Based on this review, we have identified the following market trends:

- In 2008, total retail sales of renewable energy in voluntary-purchase markets exceeded 24 billion $\mathrm{kWh}$, representing a capacity equivalent of 7,300 MW of renewable energy, including 6,300 MW from "new" renewable energy sources.

- Wind energy provided $71 \%$ of total green power sales, followed by biomass energy sources including landfill gas (17\%), hydropower $(9 \%)$, geothermal $(2 \%)$, solar $(<1 \%)$, with the remainder unknown (1\%).

- Total market sales increased by nearly $35 \%$ in 2008 , dominated by REC sales to nonresidential consumers, which increased by about $50 \%$. Commercial and institutional REC markets now represent nearly two-thirds of green power market sales, surpassing sales in competitive electricity markets and utility green pricing programs.

- Overall, the total number of customers purchasing green power increased by nearly $15 \%$ in 2008, a slower rate than in previous years, with gains primarily in competitive and REC markets. Utility green pricing program participants remained essentially flat in aggregate, with some programs reporting customer losses, presumably due to the economic downturn.

- Utility green pricing programs in regulated electricity markets continued to grow on a sales basis, but at a slower rate than in previous years, with sales increasing by about $10 \%$ in 2008. A relatively small number of utility programs continue to dominate sales and customer numbers. In fact, the termination of one large program had a significant impact on market growth. Some programs experienced growth in sales even amidst customer losses, as a result of increased sales to commercial and institutional customers.

- Utility premiums for green pricing have continued to fall, which is attributed to a combination of higher prices of conventional generation fuels and lower renewable resource costs; however, these trends have become less clear with the economic declines in late 2008.

- In 2008, nearly 250,000 tons of $\mathrm{CO}_{2} \mathrm{e}$ avoided from renewable energy facilities were marketed as offsets. This is the equivalent of about $340,000 \mathrm{MWh}$ of renewable energy generation. Offset products sourced from renewables and sold to U.S. consumers are being certified by a number of organizations including CCX, Green-e Climate, and ERT.

- In 2008, sales to nonresidential customers continued to outpace those to residential customers, bringing the fraction of nonresidential sales to more than three-quarters of all green power sales on a kilowatt-hour basis. The growing dominance of nonresidential sales is a departure from the early history of green power markets when most products and programs were oriented toward residential customers. 


\section{References}

Barbose, G. 2009. Lawrence Berkeley National Laboratory, data provided via email communication, May 21, 2008.

Bird, L.; Hurlbut, D.; Donohoo, P.; Cory, K.; Kreycik, C. (2009). An Examination of the Regional Supply and Demand Balance for Renewable Electricity in the United States through 2015. NREL/TP-6A2-45041. Golden, CO: National Renewable Energy Laboratory, March. http://www.nrel.gov/docs/fy09osti/45041.pdf

Bird, L.; Swezey, B.; Cory, K. (2008). Renewable Energy Price-Stability Benefits in Utility Green Power Programs, NREL/TP-670-43532. Golden, CO: National Renewable Energy Laboratory, August. http://apps3.eere.energy.gov/greenpower/resources/pdfs/43532.pdf

Bird, L; Kaiser, M. (2007). Trends in Utility Green Pricing Programs (2006), 2007. NREL/TP670-42287. Golden, CO: National Renewable Energy Laboratory, October. http://apps3.eere.energy.gov/greenpower/pdfs/42287.pdf

Bird, L., Kreycik, C. and Friedman, B. (2008). Green Power Marketing in the United States: A Status Report (Eleventh Edition), NREL/TP-6A2-44094. Golden, CO: National Renewable Energy Laboratory, October. http://www.nrel.gov/docs/fy09osti/44094.pdf

Bird, L.; Dagher, L.; Swezey, B. (2007). Green Power Marketing in the United States: A Status Report (Tenth Edition), NREL/TP-670-42502. Golden, CO: National Renewable Energy Laboratory, December. http://apps3.eere.energy.gov/greenpower/resources/pdfs/42502.pdf

Bird, L.; Swezey, B. (2006). Green Power Marketing in the United States: A Status Report (Ninth Edition), NREL/TP-620-40904. Golden, CO: National Renewable Energy Laboratory, November. http://www.eere.energy.gov/greenpower/resources/pdfs/40904.pdf

Bird, L.; Swezey, B. (2005a). Green Power Marketing in the United States: A Status Report (Eighth Edition), NREL/TP-620-38994. Golden, CO: National Renewable Energy Laboratory, October. http://www.eere.energy.gov/greenpower/resources/pdfs/38994.pdf

Bird, L.; Swezey, B. (2005b). Estimates of New Renewable Energy Capacity Serving U.S. Green Power Markets, National Renewable Energy Laboratory, September. http://www.eere.energy.gov/greenpower/resources/tables/new_gp_cap.shtml

Bird, L.; Swezey, B. (2004). Green Power Marketing in the United States: A Status Report (Seventh Edition), NREL/TP-620-36823. Golden, CO: National Renewable Energy Laboratory, September. http://www.eere.energy.gov/greenpower/pdfs/36823.pdf

Bird, L.; Swezey, B. (2003). Green Power Marketing in the United States: A Status Report $\left(6^{\text {th }}\right.$ Edition), NREL/TP-620-35119. Golden, CO: National Renewable Energy Laboratory, October. http://www.eere.energy.gov/greenpower/resources/pdfs/35119.pdf 
Center for Resource Solutions (CRS) (2007). 2006 Green-e Verification Report, San Francisco, California, November. http://www.green-e.org/publications.shtml

Center for Resource Solutions (CRS) (2008). National Standard Version 1.6. San Fransisco, CA, December. http://www.green-e.org/docs/energy/Appendix\%20D_Greene $\% 20$ Energy $\% 20$ National $\% 20$ Standard.pdf

Friedman, B.; Bird, L.; Barbose, G. (2008). Considerations for Emerging Markets for Energy Savings Certificates, NREL/TP-670-44072, Golden, CO: National Renewable Energy Laboratory, October. http://www.nrel.gov/docs/fy09osti/44072.pdf

Holt, E.A.; Holt, M. (2004). Green Pricing Resource Guide (2nd Edition), Ed Holt \& Associates, Inc., Harpswell, Maine. Prepared for the American Wind Energy Association, Washington DC, September. http://www.awea.org/greenpower/greenPricingResourceGuide040726.pdf

Holt, E. and R. Wiser, (2007). The Treatment of Renewable Energy Certificates, Emissions Allowances, and Green Power Programs in State Renewables Portfolio Standards. Report prepared for Lawrence Berkeley National Laboratory, Berkeley, California, April. LBNL-62574. http://eetd.lbl.gov/ea/ems/reports/62574.pdf

Karelas, A. (2009). Center for Resource Solutions, San Francisco, California, personal communication, July 5-July 22.

National Renewable Energy Laboratory (NREL). (2008). "NREL Highlights Leading Utility Green Power Programs.” News release. Accessed April 28, 2008. http://www.eere.energy.gov/greenpower/resources/tables/pdfs/0408 topten pr.pdf

Swezey, B.; Bird, L. (2001). Utility Green Pricing Programs: What Defines Success? NREL/TP620-29831. Golden, CO: National Renewable Energy Laboratory, August.

http://www.eere.energy.gov/greenpower/29831.pdf

Swezey, B.; Bird, L. (2000). Green Power Marketing in the United States: A Status Report (5 ${ }^{\text {th }}$ Edition), NREL/TP-620-28738. Golden, CO: National Renewable Energy Laboratory, August. http://www.eere.energy.gov/greenpower/resources/pdfs/28738.pdf

Swezey, B.; Bird, L. (1999). Information Brief on Green Power Marketing, 4th Edition. NREL/TP-620-26901. Golden: CO: National Renewable Energy Laboratory, August. http://www.eere.energy.gov/greenpower/resources/pdfs/26901.pdf

U.S. Energy Information Administration (EIA) (2008). Green Pricing and Net Metering Programs, 2006. July.

http://www.eia.doe.gov/cneaf/solar.renewables/page/greenprice/green pricing.html Accessed August 15, 2008.

U.S. Environmental Protection Agency (EPA) (2008). EPA Green Power Partnership. "National Top 25: as of July 8, 2008." http://www.epa.gov/greenpower/toplists/top25.htm Accessed August 15, 2008. 


\section{Appendix A. Estimates of New Renewable Energy Capacity Serving Green Power Markets, 2000-2004}

Prior to 2005, estimates of the capacity serving green power markets were estimated based on renewable energy projects used to serve green pricing programs rather than derived from renewable energy sales. Therefore, the 2005 and more recent capacity estimates are not directly comparable to capacity estimates from previous years. However, the two approaches yield relatively consistent results.

Bird and Swezey (2005b) provide details on the derivation of capacity estimates for 2004 and earlier. Table A-1 presents estimates of the cumulative new renewable energy capacity serving voluntary markets from 2000 to 2004. A brief description of the methodology is included below.

Table A-1. Estimated Cumulative New Renewable Energy Capacity Supplying Green Power Markets, 2000-2004* (Megawatts)

\begin{tabular}{|l|c|c|c|c|c|}
\hline Market & $\mathbf{2 0 0 0}$ & $\mathbf{2 0 0 1}$ & $\mathbf{2 0 0 2}$ & $\mathbf{2 0 0 3}$ & $\mathbf{2 0 0 4}$ \\
\hline Utility Green Pricing & 77 & 221 & 279 & 510 & 706 \\
\hline Competitive Markets/RECs & $\mathbf{9 0}$ & $\mathbf{5 4 2}$ & $\mathbf{6 9 5}$ & $\mathbf{1 , 1 2 6}$ & $\mathbf{1 , 5 2 8}$ \\
\hline Total $^{* *}$ & 167 & 764 & 974 & 1,636 & 2,233 \\
\hline
\end{tabular}

${ }^{*}$ Data not directly comparable with Table 4.

**Totals may not add due to rounding.

Source: Bird and Swezey (2005b).

The estimates of capacity serving green power markets for 2004 and earlier focus on new renewable resources used to serve green power customers. New renewable resources are defined as projects or portions of projects built specifically to serve green power customers, or recently constructed projects that are used to supply green power customers and meet the regional Greene Energy National Standard requirement to have come online on after January 1, 1997. The estimates do not include pre-existing renewable energy projects used for green power supply, or capacity used to meet state RPS requirements or other renewable energy mandates.

These estimates generally include the entire capacity of a given renewable energy project, regardless of whether the output has been fully subscribed by green power buyers (i.e., if a utility or developer completed a project before the entire output was sold to prospective customers). Therefore, the estimates may include some capacity for which a green power buyer was not yet secured. However, in cases where a portion of a project is used to meet a renewable energy mandate, only the remainder of the project is counted. 


\section{Appendix B. Leading Purchasers in the EPA Green Power Partnership}

Table B-1. Top 25 Purchasers in the EPA Green Power Partnership Program, July 7, 2009

\begin{tabular}{|c|c|c|c|c|}
\hline Ranking & Company & $\begin{array}{c}\text { Annual Green } \\
\text { Power Usage } \\
\text { (kWh) }\end{array}$ & $\begin{array}{l}\text { GP \% of } \\
\text { Total } \\
\text { Electricity } \\
\text { Use }\end{array}$ & Resource Type \\
\hline 1 & Intel Corporation & $1,301,300,000$ & $48 \%$ & $\begin{array}{l}\text { Biogas, Biomass, Geothermal, } \\
\text { Small-hydro, Solar, Wind }\end{array}$ \\
\hline 2 & PepsiCo & $1,226,403,121$ & $100 \%$ & Various \\
\hline 3 & Whole Foods Market & $790,459,000$ & $105 \%$ & Solar, Wind \\
\hline 4 & Kohl's Department Stores & $600,990,000$ & $50 \%$ & $\begin{array}{c}\text { Biogas, Biomass, Small-hydro, } \\
\text { Solar, Wind }\end{array}$ \\
\hline 5 & Dell Inc. & $553,708,000$ & $158 \%$ & Biogas, Solar, Wind \\
\hline 6 & City of Houston, TX & $438,000,000$ & $34 \%$ & Wind \\
\hline 7 & U.S. Air Force & $426,274,291$ & $5 \%$ & Biogas, Biomass, Solar, Wind \\
\hline 8 & $\begin{array}{l}\text { The Pepsi Bottling Group } \\
\text { Inc. }\end{array}$ & $426,239,848$ & $100 \%$ & Various \\
\hline 9 & Cisco Systems Inc. & $400,996,000$ & $46 \%$ & Wind \\
\hline 10 & $\begin{array}{l}\text { Commonwealth of } \\
\text { Pennsylvania }\end{array}$ & $400,000,000$ & $40 \%$ & Biomass, Wind \\
\hline 11 & Johnson \& Johnson & $386,455,711$ & $34 \%$ & $\begin{array}{c}\text { Biogas, Biomass, Small-hydro, } \\
\text { Solar, Wind }\end{array}$ \\
\hline 12 & City of Dallas, TX & $333,659,840$ & $40 \%$ & Wind \\
\hline 13 & HSBC North America & $300,000,000$ & $93 \%$ & Wind \\
\hline 14 & $\begin{array}{l}\text { U.S. Environmental } \\
\text { Protection Agency }\end{array}$ & $285,000,000$ & $100 \%$ & $\begin{array}{c}\text { Biogas, Biomass, Geothermal, } \\
\text { Wind }\end{array}$ \\
\hline 15 & $\begin{array}{l}\text { Wal-Mart Stores, Inc/ } \\
\text { California \& Texas } \\
\text { Facilities }\end{array}$ & $243,328,000$ & $8 \%$ & Solar, Wind \\
\hline 16 & City of Chicago, IL & $214,635,000$ & $20 \%$ & Biomass, Wind \\
\hline 17 & Starbucks & $211,291,000$ & $20 \%$ & Wind \\
\hline 18 & $\begin{array}{l}\text { Kimberly-Clark } \\
\text { Corporation }\end{array}$ & $192,730,000$ & $7 \%$ & Biomass \\
\hline 19 & $\begin{array}{l}\text { University of } \\
\text { Pennsylvania }\end{array}$ & $192,727,000$ & $46 \%$ & Wind \\
\hline 20 & $\begin{array}{l}\text { U.S. Department of } \\
\text { Energy }\end{array}$ & $188,599,600$ & $4 \%$ & Various \\
\hline 21 & DuPont Company & $180,075,000$ & $4 \%$ & Biomass, Solar, Wind \\
\hline 22 & Wells Fargo \& Company & $175,000,000$ & $14 \%$ & Wind \\
\hline 23 & $\begin{array}{l}\text { Los Angeles County } \\
\text { Sanitation Districts }\end{array}$ & $171,144,000$ & $54 \%$ & Biogas \\
\hline 24 & Deutsch Bank AG & $160,000,000$ & $97 \%$ & Wind \\
\hline 25 & PepsiAmericas Inc. & $157,128,393$ & $100 \%$ & Various \\
\hline
\end{tabular}




\section{Appendix C. Estimated U.S. Green Pricing Customers by State and Customer Class, 2006 and 2007}

Table C-1. Estimated U.S. Green Pricing Customers by State and Customer Class, 2006 and 2007

\begin{tabular}{|c|c|c|c|c|c|}
\hline \multirow[b]{3}{*}{ State } & \multirow{3}{*}{$\begin{array}{c}\text { Electric } \\
\text { Industry } \\
\text { Participants } \\
2007^{a}\end{array}$} & \multicolumn{4}{|c|}{ Participating Customers } \\
\hline & & \multicolumn{3}{|c|}{2007} & \multirow{2}{*}{$\begin{array}{r}2006 \\
\text { Total } \\
\end{array}$} \\
\hline & & Residential & Non-Residential & Total & \\
\hline Alabama & 9 & 580 & 5 & 585 & 163 \\
\hline Alaska & 1 & 520 & 10 & 530 & 356 \\
\hline Arizona & 5 & 9,125 & 160 & 9,285 & 1,933 \\
\hline Arkansas & 0 & 0 & 0 & 0 & 0 \\
\hline California & 11 & 56,380 & 2,296 & 58,676 & 47,527 \\
\hline Colorado & 23 & 55,635 & 1,866 & 57,501 & 48,093 \\
\hline Connecticut & 3 & 90 & 6 & 96 & 0 \\
\hline Delaware & 9 & 7,322 & 1,592 & 8,914 & 2,568 \\
\hline District of Columbia & 3 & 1,351 & 3,503 & 4,854 & 3,716 \\
\hline Florida & 6 & 37,536 & 297 & 37,833 & 29,301 \\
\hline Georgia & 19 & 8,135 & 173 & 8,308 & 5,983 \\
\hline Hawaii & 3 & 4,698 & 40 & 4,738 & 4,466 \\
\hline Idaho & 6 & 4,669 & 148 & 4,817 & 4,130 \\
\hline Illinois & 8 & 3,859 & 33 & 3,892 & 2,770 \\
\hline Indiana & 14 & 4,244 & 55 & 4,299 & 2,039 \\
\hline lowa & 45 & 8,385 & 808 & 9,193 & 8,562 \\
\hline Kansas & 1 & 1 & 0 & 1 & 0 \\
\hline Kentucky & 13 & 1,322 & 16 & 1,338 & 889 \\
\hline Louisiana & 0 & 0 & 0 & 0 & 0 \\
\hline Maine & 2 & 2,266 & 228 & 2,494 & 2,146 \\
\hline Maryland & 4 & 40,058 & 15,896 & 55,954 & 37,048 \\
\hline Massachusetts & 5 & 5,882 & 273 & 6,155 & 5,655 \\
\hline Michigan & 8 & 13,002 & 194 & 13,196 & 7,992 \\
\hline Minnesota & 106 & 43,428 & 606 & 44,034 & 32,342 \\
\hline Mississippi & 1 & 3 & 0 & 3 & 3 \\
\hline Missouri & 17 & 1,417 & 22 & 1,439 & 459 \\
\hline Montana & 13 & 974 & 21 & 995 & 460 \\
\hline Nebraska & 5 & 6,831 & 60 & 6,891 & 4,887 \\
\hline Nevada & 3 & 513 & 1 & 514 & 379 \\
\hline New Hampshire & 1 & 0 & 1 & 1 & 0 \\
\hline New Jersey & 3 & 146 & 295 & 441 & 363 \\
\hline New Mexico & 13 & 19,339 & 1,934 & 21,273 & 15,577 \\
\hline New York & 10 & 20,142 & 1,715 & 21,857 & 22,431 \\
\hline North Carolina & 22 & 11,992 & 394 & 12,386 & 9,480 \\
\hline North Dakota & 10 & 5,065 & 21 & 5,086 & 5,846 \\
\hline Ohio & 14 & 1,784 & 5 & 1,789 & 252 \\
\hline Oklahoma & 10 & 10,645 & 642 & 11,287 & 11,292 \\
\hline Oregon & 17 & 97,400 & 3,195 & 100,595 & 80,733 \\
\hline
\end{tabular}




\begin{tabular}{|c|c|c|c|c|c|}
\hline \multirow[b]{3}{*}{ State } & \multirow{3}{*}{\begin{tabular}{|c|} 
Electric \\
Industry \\
Participants \\
$2007^{\mathrm{a}}$ \\
\end{tabular}} & \multicolumn{4}{|c|}{ Participating Customers } \\
\hline & & \multicolumn{3}{|c|}{2007} & \multirow{2}{*}{$\frac{2006}{\text { Total }}$} \\
\hline & & Residential & Non-Residential & Total & \\
\hline Pennsylvania & 4 & 38,301 & 798 & 39,099 & 37,355 \\
\hline Rhode Island & 2 & 4,776 & 111 & 4,887 & 4,516 \\
\hline South Carolina & 14 & 4,362 & 404 & 4,766 & 3,535 \\
\hline South Dakota & 7 & 615 & 17 & 632 & 640 \\
\hline Tennessee & 0 & 0 & 0 & 0 & 0 \\
\hline Texas & 18 & 125,849 & 16,485 & 142,334 & 100,950 \\
\hline Utah & 6 & 22,873 & 533 & 23,406 & 20,188 \\
\hline Vermont & 2 & 4,281 & 236 & 4,517 & 4,537 \\
\hline Virginia & 2 & 1,304 & 2 & 1,306 & 2,678 \\
\hline Washington & 25 & 42,949 & 936 & 43,885 & 35,986 \\
\hline West Virginia & 0 & 0 & 0 & 0 & 0 \\
\hline Wisconsin & 60 & 34,252 & 2,092 & 36,344 & 31,335 \\
\hline Wyoming & 8 & 9,090 & 4,135 & 13,225 & 3,606 \\
\hline Total & 591 & 775,398 & 62,260 & 835,651 & 645,167 \\
\hline
\end{tabular}

${ }^{a}$ Includes entities with green pricing programs in more than one state.

Note: Nonresidential may include some customers for whom no customer class is specified. Blank cells indicate no data was reported for the state or the number of customers in a class was zero. Totals may not sum due to rounding.

Source: Energy Information Administration, Green Pricing and Net Metering Programs, 2007. April 2009.

http://www.eia.doe.gov/cneaf/solar.renewables/page/greenprice/table5 1.html

Table C-2. Estimated U.S. Green Pricing Customers by Customer Class, 2002-2007

\begin{tabular}{|c|c|c|c|c|}
\hline \multirow[b]{3}{*}{ Year } & \multirow{3}{*}{$\begin{array}{c}\text { Electric } \\
\text { Industry } \\
\text { Participants }\end{array}$} & \multicolumn{2}{|c|}{ Participating Customers } & \multirow[b]{3}{*}{ Total** } \\
\hline & & \multicolumn{2}{|c|}{ Customer Class } & \\
\hline & & Residential & $\begin{array}{c}\text { Non- } \\
\text { residential* }^{*}\end{array}$ & \\
\hline 2002 & 212 & 688,069 & 23,481 & 711,550 \\
\hline 2003 & 308 & 819,579 & 57,547 & 877,126 \\
\hline 2004 & 403 & 864,794 & 63,539 & 928,333 \\
\hline 2005 & 442 & 871,774 & 70,998 & 942,772 \\
\hline 2006 & 484 & 609,213 & 35,954 & 645,167 \\
\hline 2007 & 591 & 775,398 & 62,260 & 835,651 \\
\hline
\end{tabular}

${ }^{*}$ Note: Nonresidential may include some customers for whom no customer class is specified.

**Totals may not sum due to rounding.

Source: Energy Information Administration, Green Pricing and Net Metering Programs, 2006. July 2009. http://www.eia.doe.gov/cneaf/solar.renewables/page/greenprice/table4 h1.pdf and

Green Pricing and Net Metering Programs, 2007. April 2009.

http://www.eia.doe.gov/cneaf/solar.renewables/page/greenprice/table5 1.html 


\section{Appendix D. Utilities Offering Green Pricing Programs in Regulated Markets, 2008}

Table D-1. Utilities Offering Green Pricing Programs in Regulated Markets, 2008

Investor-Owned Utilities

AEP Appalachian Power AEP Ohio

Alabama Power Company

Alliant Energy

AmerenUE

Arizona Public Service

Avista Utilities

Central Vermont Public Service

Cheyenne Light, Fuel and Power Company

Connecticut Light and Power

Consumers Energy

Dayton Power and Light

Dominion North Carolina Power

Dominion Virginia Power

DTE Energy

Duke Energy

El Paso Electric Company

Entergy Gulf States

E.ON U.S.

FirstEnergy

Georgia Power

Green Mountain Power

Gulf Power Company

Hawaiian Electric Company

Idaho Power Company

Indianapolis Power \& Light Company

Kansas City Power \& Light

Kentucky Power Co.

Kentucky Utilities Company

Louisville Gas and Electric Company

Madison Gas and Electric

MidAmerican Energy

Minnesota Power

NSTAR Electric

Nevada Power

Nevada Power

NorthWestern Energy

OG\&E Electric Services

Otter Tail Power Company

PacifiCorp

Portland General Electric Company

Progress Energy

Public Service Company of New Mexico

Puget Sound Energy

SCE\&G

Savannah Electric

Tampa Electric Company

Tucson Electric Power Company

UniSource Energy Services

United Illuminating

Upper Peninsula Power Company

Vectren Energy Delivery of Indiana

We Energies

Wisconsin Public Service Corporation

Xcel Energy

\section{Electric Cooperatives}

Alabama Electric Cooperative Associated Electric Cooperative Inc. Bandera Electric Cooperative Basin Electric Power Cooperative Boone Electric Cooperative
Buckeye Power

Central Electric Cooperative

Central lowa Power Cooperative

Connexus Energy

Corn Belt Power Cooperatives

Dairyland Power Cooperative

Dakota Electric Association

Delaware Electric Cooperative

Deseret Power

Deseret Power/Mt. Wheeler Power Cooperative Eugene Water \& Electric Board

East Kentucky Power Cooperative

Electric Cooperatives of Arkansas

Farmers Electric Cooperative

Flathead Electric Cooperative

Georgia Electric Membership Corporation

Golden Valley Electric Association

Great River Energy

Gunnison County Electric Association

Holy Cross Energy

Hoosier Energy

Intermountain Rural Electric Association

KAMO Electric Cooperative

Kauai Island Utility Cooperative (KIUC)

La Plata Electric Association

Lower Colorado River Authority

Lower Valley Energy

Midstate Electric Cooperative

Minnkota Power Cooperative

New-Mac Electric Cooperative

Orcas Power \& Light

Oregon Trail Electric Cooperative

Palmetto Electric Cooperative

Park Electric Cooperative

Pedernales Electric Cooperative

Peninsula Light Company

PNGC Power

Prairie Power (formerly CCS/Soyland)

Southern Montana Electric G\&T Cooperative

Tri-State Generation and Transmission Association

Vigilante Electric Cooperative

Wabash Valley Power Association

Western Farmers Electric Cooperative

Yampa Valley Electric Association

Federal

\section{Municipal/Public Utilities}

City of Alameda

American Municipal Power-Ohio

Anaheim Public Utilities

City of Ashland

Austin Energy

Austin Utilities (MN)

Benton County Public Utility District

City of Bowling Green

Braintree Electric Light Department

Burbank Water and Power

CPS Energy (San Antonio)

Cedar Falls Utilities

Central Minnesota Municipal Power Agency

Chelan County Public Utility District

Clallam County PUD

Clark Public Utilities

College Station Utilities (TX)
Colorado Springs Utilities

Columbia River PUD

Concord Municipal Light Plant

Cowlitz PUD

Edmond Electric

City of Eldridge (IA)

ElectriCities

Emerald People's Utility District

Estes Park Light and Power

Fort Collins Utilities

Gainesville Regional Utilities

Grant County PUD

Grays Harbor PUD

Heartland Consumers Power District

lowa Association of Municipal Utilities

Keys Energy Services

Lakeland Electric

Lansing Board of Water and Light

Lenox Municipal Utilities

Lewis County PUD

Lincoln Electric System

Lodi Utilities

Longmont Power \& Communications

Los Alamos County (NM)

Los Angeles Department of Water and Power

Loveland Water \& Power

Mason County PUD No. 3

Missouri Joint Municipal Electric Utility

Missouri River Energy Services

Moorhead Public Service

Muscatine Power and Water

City of Naperville

City of New Smyrna Beach

Northern Wasco County PUD

Oklahoma Municipal Power Authority

Omaha Public Power District

Owatonna Public Utilities

Pacific County PUD

City of Palo Alto Utilities

Pasadena Water \& Power

Platte River Power Authority

Rochester Public Utilities (MN)

Roseville Electric

Sacramento Municipal Utility District

Salt River Project

San Francisco Public Utilities Commission

Santee Cooper

Seattle City Light

Consumer Protection

Federal Trade Commission

Green Pricing Accreditation

Low Impact Hydro Institute

Federal

Tennessee Valley Authority 


\section{Table D-2. Utility/Marketer Green Power Programs in Restructured Electricity}

Markets, 2008

Atlantic City Electric

Consumers Energy

Connecticut Light \& Power

JP\&L

Kennebunk Light and Power District

Long Island Power Authority

National Grid (Massachusetts Electric, Nantucket

Electric, Narragansett Electric, Niagara Mohawk)

NYSEG

Rochester Gas and Electric

Rockland Electric

PECO Energy

PSE\&G

United Illuminating 


\section{Appendix E. Links to Utility Green Pricing Programs, and REC and Competitive-Market Green Power Offerings}

Table of Utility Green Pricing Programs by State:

http://www.eere.energy.gov/greenpower/markets/pricing.shtml?page=1

Renewable Energy Certificate Retail Products:

http://www.eere.energy.gov/greenpower/markets/certificates.shtml?page=1

Retail Green Power Product Offerings in States with Retail Competition:

http://www.eere.energy.gov/greenpower/markets/marketing.shtml?page $=1$ 


\section{Appendix F. Top Ten Utility Green Pricing Programs}

\section{Table F-1. Green Pricing Program Renewable Energy Sales (as of December 2008)}

\begin{tabular}{|c|c|c|c|c|}
\hline Rank & Utility & Resources Used & $\begin{array}{c}\text { Sales } \\
\text { (kWh/year) }\end{array}$ & $\begin{array}{l}\text { Sales } \\
(\text { aMW })^{\mathrm{a}}\end{array}$ \\
\hline 1 & Austin Energy & Wind, landfill gas & $723,824,901$ & 82.6 \\
\hline 2 & Portland General Electric ${ }^{b}$ & Geothermal, wind & $672,469,949$ & 76.8 \\
\hline 3 & PacifiCorp ${ }^{\text {cde }}$ & $\begin{array}{l}\text { Wind, biomass, landfill } \\
\text { gas, solar }\end{array}$ & $492,892,222$ & 56.3 \\
\hline 4 & Xcel Energy ${ }^{\text {ef }}$ & Wind & $362,040,082$ & 41.3 \\
\hline 5 & Sacramento Municipal Utility District ${ }^{\mathrm{e}}$ & $\begin{array}{l}\text { Wind, solar, biomass, } \\
\text { landfill gas, hydro }\end{array}$ & $325,275,628$ & 37.1 \\
\hline 6 & Puget Sound Energy $^{\mathrm{e}}$ & $\begin{array}{l}\text { Wind, solar, biomass, } \\
\text { landfill gas, hydro }\end{array}$ & $291,166,600$ & 33.2 \\
\hline 7 & Public Service Company of New Mexico & Wind & $176,497,697$ & 20.1 \\
\hline 8 & We Energies ${ }^{e}$ & Wind, landfill gas, solar & $176,242,630$ & 20.1 \\
\hline 9 & National Grid ${ }^{\text {gh }}$ & $\begin{array}{l}\text { Biomass, wind, small } \\
\text { hydro, solar }\end{array}$ & $174,612,444$ & 19.9 \\
\hline 10 & $\mathrm{PECO}^{\mathrm{i}}$ & Wind & $173,375,000$ & 19.8 \\
\hline
\end{tabular}

a An "average megawatt" (aMW) is a measure of continuous capacity equivalent (i.e., operating at a $100 \%$ capacity factor).

b Marketed in partnership with Green Mountain Energy Company. For Portland General Electric, some products marketed in partnership with Green Mountain Energy Company.

c Includes Pacific Power and Rocky Mountain Power.

d Some Oregon products marketed in partnership with 3Degrees Group Inc.

e Product is Green-e Energy certified. For Xcel Energy, the Colorado and Minnesota Windsource products are Green-e Energy certified.

f Includes Northern States Power, Public Service Company of Colorado, and Southwestern Public Service.

g Includes Niagara Mohawk, Massachusetts Electric, Narragansett Electric, and Nantucket Electric.

h Marketed in partnership with Community Energy Inc., EnviroGen, Green Mountain Energy Company, Mass Energy, People's Power \& Light, and Sterling Planet.

i Marketed in partnership with Community Energy Inc. 
Table F-2. Total Number of Customer Participants

(as of December 2008)

\begin{tabular}{|c|c|c|c|}
\hline Rank & Utility & Program(s) & Participants \\
\hline 1 & Xcel Energy ${ }^{a}$ & $\begin{array}{l}\text { Windsource } \\
\text { Renewable Energy Trust }\end{array}$ & 71,571 \\
\hline 2 & Portland General Electric ${ }^{\mathrm{cg}}$ & $\begin{array}{l}\text { Clean Wind } \\
\text { Green Source }\end{array}$ & 69,258 \\
\hline 3 & PacifiCorp ${ }^{\text {de }}$ & $\begin{array}{l}\text { Blue Sky Block }{ }^{\mathrm{b}} \\
\text { Blue Sky Usage } \\
\text { Blue Sky Habitat }\end{array}$ & 67,252 \\
\hline 4 & Sacramento Municipal Utility District & Greenergy $^{\mathrm{b}}$ & 45,992 \\
\hline 5 & $\mathrm{PECO}^{\mathrm{f}}$ & PECO WIND & 36,300 \\
\hline 6 & National Grid ${ }^{\text {hi }}$ & GreenUp & 23,668 \\
\hline 7 & Energy East (NYSEG/RGE) ${ }^{\mathrm{f}}$ & Catch the Wind & 22,210 \\
\hline 8 & Puget Sound Energy & Green Power Program ${ }^{\mathrm{b}}$ & 21,509 \\
\hline 9 & Los Angeles Department of Water \& Power & $\begin{array}{l}\text { Green Power for } \\
\text { a Green LA }\end{array}$ & 21,113 \\
\hline 10 & We Energies & Energy for Tomorrow ${ }^{\mathrm{b}}$ & 19,615 \\
\hline
\end{tabular}

a Includes Northern States Power, Public Service Company of Colorado, and Southwestern Public Service.

b Product is Green-e Energy certified. For Xcel Energy, the Colorado and Minnesota Windsource products are Green-e Energy certified.

c Some products marketed in partnership with Green Mountain Energy Company.

d Includes Pacific Power and Rocky Mountain Power.

e Some Oregon products marketed in partnership with 3Degrees Group Inc.

f Marketed in partnership with Community Energy Inc.

g Marketed in partnership with Green Mountain Energy Company.

h Includes Niagara Mohawk, Massachusetts Electric, Narragansett Electric, and Nantucket Electric.

i Marketed in partnership with Community Energy, EnviroGen, Green Mountain Energy Company, Mass Energy, People's

Power \& Light, and Sterling Planet. 


\section{Table F-3. Customer Participation Rate}

(as of December 2008)

\begin{tabular}{|c|c|c|c|c|}
\hline Rank & Utility & $\begin{array}{c}\text { Customer } \\
\text { Participation } \\
\text { Rate }\end{array}$ & Program(s) & $\begin{array}{c}\text { Program } \\
\text { Start } \\
\text { Year }\end{array}$ \\
\hline 1 & City of Palo Alto Utilities ${ }^{\text {ab }}$ & $21.0 \%$ & Palo Alto Green & 2003 \\
\hline 2 & Lenox Municipal Utilities ${ }^{c}$ & $10.5 \%$ & Green City Energy & 2003 \\
\hline 3 & Portland General Electric ${ }^{\mathrm{d}}$ & $9.7 \%$ & $\begin{array}{l}\text { Clean Wind } \\
\text { Green Source } \\
\text { Renewable Future }\end{array}$ & 2002 \\
\hline 4 & Madison Gas and Electric Company & $9.6 \%$ & Green Power Tomorrow & 1999 \\
\hline 5 & Silicon Valley Power ${ }^{a b}$ & $8.4 \%$ & Santa Clara Green Power & 2004 \\
\hline 6 & Sacramento Municipal Utility District ${ }^{\mathrm{b}}$ & $7.8 \%$ & Greenergy & 1997 \\
\hline 7 & City of Naperville Public Utilities ${ }^{\mathrm{e}}$ & $7.8 \%$ & Renewable Energy Program & 2005 \\
\hline 8 & Pacific Power - (Oregon only) ${ }^{a b}$ & $6.2 \%$ & $\begin{array}{l}\text { Blue Sky Block } \\
\text { Blue Sky Usage } \\
\text { Blue Sky Habitat }\end{array}$ & 2002 \\
\hline 9 & River Falls Municipal Utilities ${ }^{\mathrm{f}}$ & $5.3 \%$ & Renewable Energy Program & 2001 \\
\hline 10 & Pacific Power ${ }^{a b}$ & $5.2 \%$ & $\begin{array}{l}\text { Blue Sky Block } \\
\text { Blue Sky Usage } \\
\text { Blue Sky Habitat }\end{array}$ & 2002 \\
\hline
\end{tabular}

${ }^{\text {a }}$ Marketed in partnership with 3Degrees Group Inc.

${ }^{\mathrm{b}}$ Product is Green-e Energy certified (www.green-e.org).

${ }^{\mathrm{c}}$ Program offered in association with the Iowa Association of Municipal Utilities.

$\mathrm{d}$ Some products marketed in partnership with Green Mountain Energy Company.

${ }^{\mathrm{e}}$ Marketed in partnership with Community Energy Inc.

f Power supplied by Wisconsin Public Power Inc. 
Table F-4. Green Power Sales as a Percentage of Total Retail Electricity Sales (in kWh) (as of December 2008)

\begin{tabular}{|c|c|c|c|}
\hline Rank & Utility & Program Name & $\%$ of Load \\
\hline 1 & Edmond Electric ${ }^{\text {a }}$ & Pure \& Simple & $6.4 \%$ \\
\hline 2 & Austin Energy & GreenChoice & $6.0 \%$ \\
\hline 3 & River Falls Municipal Utilities ${ }^{b}$ & $\begin{array}{l}\text { Renewable Energy } \\
\text { Program }\end{array}$ & $5.8 \%$ \\
\hline 4 & City of Palo Alto Utilities ${ }^{\text {ce }}$ & PaloAltoGreen & $5.7 \%$ \\
\hline 5 & Portland General Electric ${ }^{d}$ & $\begin{array}{l}\text { Clean Wind } \\
\text { Green Source } \\
\text { Renewable Future }\end{array}$ & $3.9 \%$ \\
\hline 6 & Madison Gas and Electric Company & Green Power Tomorrow & $3.8 \%$ \\
\hline 7 & Pacific Power - (Oregon only) ${ }^{\text {ce }}$ & $\begin{array}{l}\text { Blue Sky Usage } \\
\text { Blue Sky Habitat }\end{array}$ & $3.3 \%$ \\
\hline 8 & Sacramento Municipal Utility District ${ }^{\mathrm{e}}$ & Greenergy & $3.0 \%$ \\
\hline 9 & Fort Collins Utilities ${ }^{\mathrm{e}, \mathrm{f}}$ & Green Energy Program & $2.6 \%$ \\
\hline 10 & Emerald People's Utility District & EPUD Renewables & $2.2 \%$ \\
\hline
\end{tabular}

${ }^{a}$ Power supplied by Oklahoma Municipal Power Authority.

b Power supplied by Wisconsin Public Power Inc.

c Marketed in partnership with 3Degrees Group Inc.

${ }^{d}$ Marketed in partnership with Green Mountain Energy Company.

e Product is Green-e Energy certified (www.green-e.org)

f Power supplied by Platte River Power Authority 
Table F-5. Price Premium Charged for New, Customer-Driven Renewable Power ${ }^{a}$ (as of December 2008)

\begin{tabular}{|c|c|c|c|}
\hline Rank & Utility & Resources Used & $\begin{array}{c}\text { Premium } \\
(\mathbf{c} / \mathbf{k W h})\end{array}$ \\
\hline 1 & OG\&E Electric Services ${ }^{b}$ & Wind & -1.01 \\
\hline 2 & Edmond Electric ${ }^{\text {bc }}$ & Wind & -0.94 \\
\hline 3 & Indianapolis Power and Light & Wind, landfill gas & 0.07 \\
\hline 4 & Avista Utilities & Wind, landfill gas, biomass & 0.33 \\
\hline 5 & Park Electric Cooperative & Wind & 0.44 \\
\hline 6 & Austin Energy be & Wind, landfill gas & 0.69 \\
\hline 7 & PacifiCorp ${ }^{\mathrm{dg}}$ & Wind, biomass, landfill gas, solar & 0.78 \\
\hline 8 & Emerald People's Utility District & Wind & 0.80 \\
\hline 8 & Basin Electric Power Cooperative ${ }^{\mathrm{h}}$ & Wind & 0.80 \\
\hline 8 & Clallam County Public Utility District ${ }^{\text {b }}$ & Landfill gas & 0.80 \\
\hline 10 & Xcel Energy (Minnesota) ${ }^{\text {bdf }}$ & Wind & 0.91 \\
\hline
\end{tabular}

a Includes only programs that have installed or announced firm plans to install or purchase power from $100 \%$ new renewable resources.

${ }^{\mathrm{b}}$ Premium is variable; customers in these programs are exempt or otherwise protected from changes in utility fuel charges.

${ }^{\mathrm{c}}$ Power supplied by Oklahoma Municipal Power Authority.

d Product is Green-e Energy certified (www.green-e.org).

e The price for new customers enrolling in the program (fifth batch of renewable energy capacity)

$\mathrm{f}$ Net premium of the Minnesota Windsource program.

g Pacific Power Blue Sky Usage and Blue Sky Habitat products; only available in Oregon. Product marketed in partnership with 3Degrees Group Inc.

h A number of Basin Electric Power Cooperatives offer green power at a premium of $0.8 \notin / \mathrm{kWh}$. 


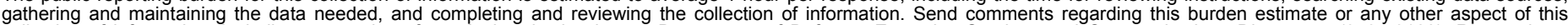

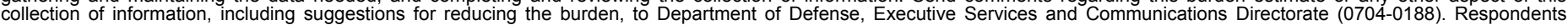

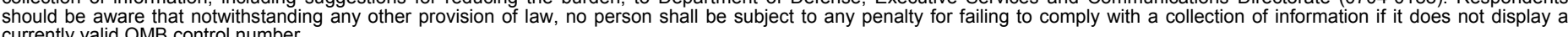

PLEASE DO NOT RETURN YOUR FORM TO THE ABOVE ORGANIZATION.

\begin{tabular}{l|l|l|l} 
1. REPORT DATE $(D D-M M-Y Y Y Y)$ & 2. & REPORT TYPE & 3. DATES COVERED (FrOm - TO)
\end{tabular} September 2009

Technical Report

4. TITLE AND SUBTITLE

Green Power Marketing in the United States: A Status Report

(2008 Data)

5a. CONTRACT NUMBER

DE-AC36-08-GO28308

5b. GRANT NUMBER

5c. PROGRAM ELEMENT NUMBER

6. AUTHOR(S)

L. Bird, C. Kreycik, and B. Friedman

5d. PROJECT NUMBER

NREL/TP-6A2-46581

5e. TASK NUMBER

SA09.3004

5f. WORK UNIT NUMBER
7. PERFORMING ORGANIZATION NAME(S) AND ADDRESS(ES)

National Renewable Energy Laboratory

1617 Cole Blvd.

Golden, CO 80401-3393

9. SPONSORING/MONITORING AGENCY NAME(S) AND ADDRESS(ES)
8. PERFORMING ORGANIZATION REPORT NUMBER

NREL/TP-6A2-46581

10. SPONSOR/MONITOR'S ACRONYM(S) NREL

11. SPONSORING/MONITORING AGENCY REPORT NUMBER

12. DISTRIBUTION AVAILABILITY STATEMENT

National Technical Information Service

U.S. Department of Commerce

5285 Port Royal Road

Springfield, VA 22161

\section{SUPPLEMENTARY NOTES}

\section{ABSTRACT (Maximum 200 Words)}

Voluntary consumer decisions to buy electricity supplied from renewable energy sources represent a powerful market support mechanism for renewable energy development. In the early 1990s, a small number of U.S. utilities began offering "green power" options to their customers. Since then, these products have become more prevalent, both from traditional utilities and from renewable energy marketers operating in states that have introduced competition into their retail electricity markets or offering renewable energy certificates (RECs) online. Today, more than half of all U.S. electricity customers have an option to purchase some type of green power product directly from a retail electricity provider, while all consumers have the option to purchase RECs. This report documents green power marketing activities and trends in the United States including utility green pricing programs offered in regulated electricity markets; green power marketing activity in competitive electricity markets, as well as green power sold to voluntary purchasers in the form of RECs; and renewable energy sold as greenhouse gas offsets in the United States. These sections are followed by a discussion of key market trends and issues. The final section offers conclusions and observations.

\section{SUBJECT TERMS}

NREL; Lori Bird; Claire Kreycik; Barry Friedman; renewable energy certificates; RECs; energy consumers; electricity; green power marketing; green pricing; renewable energy; electricity markets; utilities; greenhouse gas offsets

\begin{tabular}{|c|c|c|c|c|}
\hline \multicolumn{3}{|c|}{ 16. SECURITY CLASSIFICATION OF: } & \multirow{2}{*}{$\begin{array}{l}\text { 17. LIMITATION } \\
\text { OF ABSTRACT } \\
\text { UL }\end{array}$} & \multirow{2}{*}{$\begin{array}{l}\text { 18. NUMBER } \\
\text { OF PAGES }\end{array}$} \\
\hline $\begin{array}{l}\text { a. REPORT } \\
\text { Unclassified }\end{array}$ & $\begin{array}{l}\text { b. ABSTRACT } \\
\text { Unclassified }\end{array}$ & $\begin{array}{l}\text { c. THIS PAGE } \\
\text { Unclassified }\end{array}$ & & \\
\hline
\end{tabular}

19b. TELEPHONE NUMBER (Include area code) 